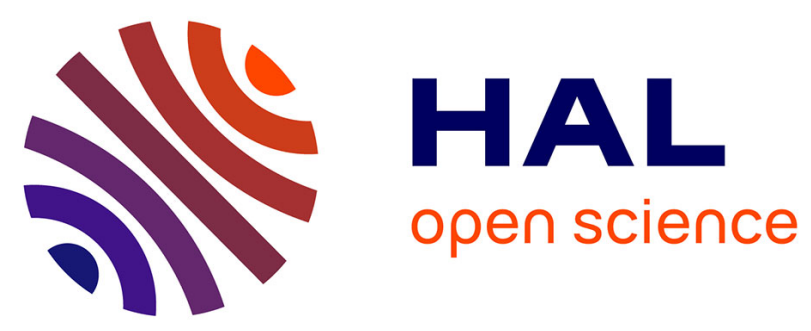

\title{
Geometry and kinematics of Mykonos detachment, Cyclades, Greece: Evidence for slip at shallow dip
}

Emmanuel Lecomte, Laurent Jolivet, Olivier Lacombe, Yoann Denèle, Loic Labrousse, Laetitia Le Pourhiet

\section{- To cite this version:}

Emmanuel Lecomte, Laurent Jolivet, Olivier Lacombe, Yoann Denèle, Loic Labrousse, et al.. Geometry and kinematics of Mykonos detachment, Cyclades, Greece: Evidence for slip at shallow dip. Tectonics, 2010, 29 (5), pp.1-22. 10.1029/2009TC002564 . hal-00591569

\section{HAL Id: hal-00591569 \\ https://hal.science/hal-00591569}

Submitted on 24 Nov 2016

HAL is a multi-disciplinary open access archive for the deposit and dissemination of scientific research documents, whether they are published or not. The documents may come from teaching and research institutions in France or abroad, or from public or private research centers.
L'archive ouverte pluridisciplinaire HAL, est destinée au dépôt et à la diffusion de documents scientifiques de niveau recherche, publiés ou non, émanant des établissements d'enseignement et de recherche français ou étrangers, des laboratoires publics ou privés. 


\title{
Geometry and kinematics of Mykonos detachment, Cyclades, Greece: Evidence for slip at shallow dip
}

\author{
Emmanuel Lecomte, ${ }^{1}$ Laurent Jolivet, ${ }^{1}$ Olivier Lacombe, ${ }^{1}$ Yoann Denèle, ${ }^{1}$ \\ Loic Labrousse, ${ }^{1}$ and Laetitia Le Pourhiet ${ }^{1}$ \\ Received 7 July 2009; revised 31 March 2010; accepted 29 April 2010; published 28 September 2010.
}

[1] The eastern part of Mykonos island (Cyclades, Greece) shows the detailed internal structure of a two-branch shallow-dipping extensional detachment system of Miocene age. This paper shows that the last stage of slip along the detachment, during the deposition of syn-rift sediments, occurred with a very low dip and proposes that this geometry prevailed since the initiation of extension. Extensional deformation during and after a $13 \mathrm{Ma}$ old granite intrusion is taken up by two main shallow-dipping shear zones: (1) The lower Livada detachment, which extends laterally across Tinos island, is a ductile structure located at the interface between the granite and the Upper Cycladic Nappe metabasites. A pervasive top-to-the-NE shearing deformation is observed throughout the granite in this island with a strong gradient toward the intrusive contact. Later brittle faults, shallowly and steeply dipping, rework the ductile deformation with the same overall shear sense. (2) The upper Mykonos detachment is brittle and separates the metabasites from late Miocene sandstones and conglomerates. The detachment fault dips $12-15^{\circ}$ toward the NNE, and its sense of shear is consistent with that of the Livada detachment. Soft-sediment deformation during the time of detachment faulting and the presence of steep normal faults that root into the detachment gouge indicate a shallow depth of deformation. Rotations about vertical and horizontal axes can be reconstructed within and below the detachment zone, indicating that the overall direction of extension is NNE/SSW with a sense of shear toward the NNE and the dip of the fault is throughout very low. The two detachments have accommodated several tens of kilometers of horizontal extension during the formation of the Aegean Sea, which emphasizes the importance of low-angle extensional faults and shear zones in extensional tectonics. Citation: Lecomte, E., L. Jolivet, O. Lacombe, Y. Denèle, L. Labrousse, and L. Le Pourhiet (2010), Geometry and kinematics of Mykonos detachment, Cyclades, Greece: Evidence for slip at shallow dip, Tectonics, 29, TC5012, doi:10.1029/2009TC002564.

\footnotetext{
${ }^{1}$ Institut des Sciences de la Terre de Paris, UMR 7193, UPMC Université Paris 6, CNRS, Paris, France.

Copyright 2010 by the American Geophysical Union. 0278-7407/10/2009TC002564
}

\section{Introduction}

[2] Extensional detachments and metamorphic core complexes (MCC) were first described in the Basin and Range Province based on field observations. Their geometry and kinematics are now well-constrained. MCC are often capped by shallow-dipping detachments separating brittlely and ductilely deformed domains [Davis and Coney, 1979; Crittenden et al., 1980; Wernicke, 1981; Lister et al., 1984; Davis and Lister, 1988]. A detachment is characterized by a low-angle extensional shear zone or normal fault juxtaposing an unmetamorphosed upper crustal unit above a deeper metamorphic unit. A detachment commonly evolves from a shallow-dipping ductile extensional shear zone toward a low-angle normal fault through a late brittle localization during exhumation [Lister and Davis, 1989; Mehl et al., 2005, 2007].

[3] The original attitude of low-angle normal fault/ detachment and the feasibility of slip at shallow dip are much debated. Depending partly on the depth level of exposure, on the scale of observation and/or on local geologic conditions, geophysical and/or geological evidence support either "rotation" of the detachment or "listric faulting" in certain places, or static low-angle dips in other locations. Classical laws of faults mechanics, assuming a vertical maximal principal stress $\sigma_{1}$, predict that low-angle normal fault (dipping less than $30^{\circ}$ ) cannot be active and, thus, favor a rotation of an initially steeply dipping fault, tilted by later steep faults or isostatic rebound [Davis, 1983; Buck, 1988; Brun et al., 1994; Gautier and Brun, 1994a; Gautier et al., 1999]. Wernicke and Axen [1988] suggested that this solution may explain some natural situations but not all of them, especially when seismic or seismological data clearly show active faulting at low dip in the brittle crust [Rigo et al., 1996; Barchi et al., 1998]. Moreover, several field studies [Longwell, 1945; Reynolds and Spencer, 1985; Lister and Davis, 1989; Froitzheim and Eberli, 1990; Johnson and Loy, 1992; Scott and Lister, 1992; Jolivet and Patriat, 1999; Sorel, 2000; Mehl et al. 2005; this study] argue in favor of an initially shallow-dipping normal fault attitude. At these places, slip is made possible by the intrinsic weakness of the fault and/or a local reorientation of the stress field [Spencer and Chase, 1989; Yin, 1989; Melosh, 1990], the presence of fluids that induced reaction softening in the rocks [Gueydan et al., 2003, 2004; Famin et al., 2004, 2005] and a decrease of the effective strength of rocks [Chéry, 2001], the presence of a preexisting shallow dipping nappe with a competence contrast with the crust [Le Pourhiet et al., 2004,2006 ] or simply by dynamic interactions between 


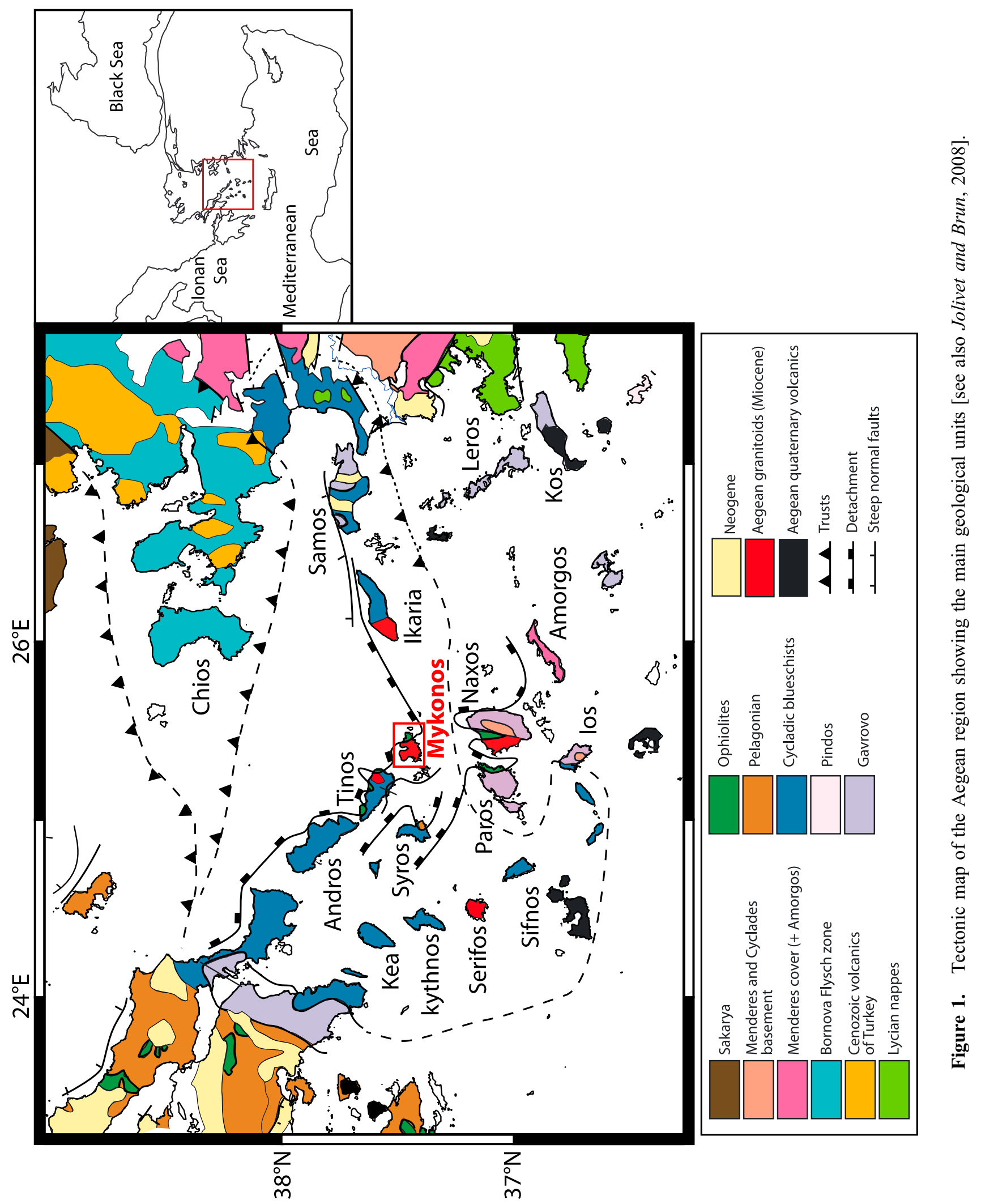




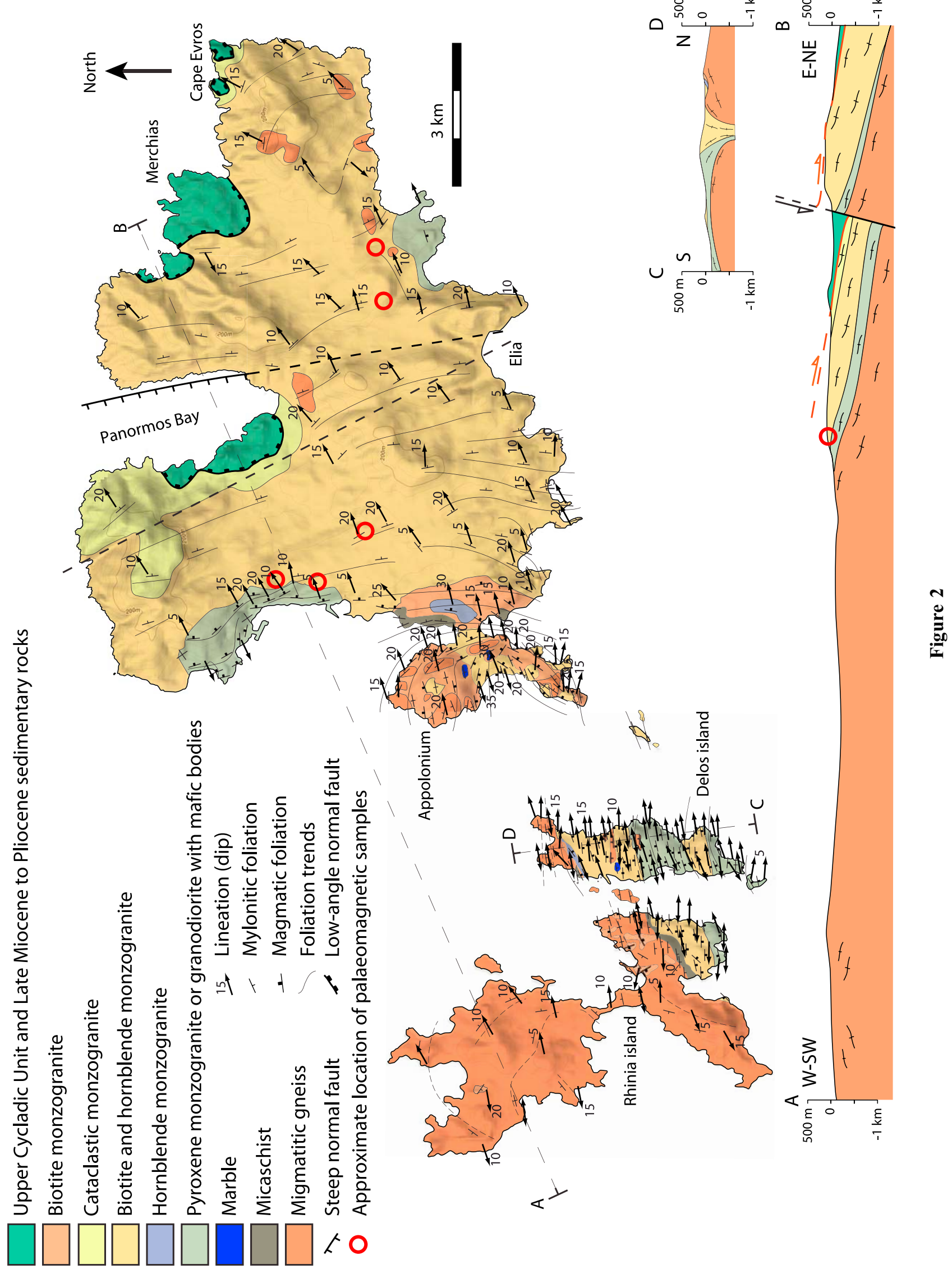


brittle and ductile layers without any particular assumption about fluids or anisotropy [Regenauer-Lieb et al., 2006].

[4] On Mykonos island, in the central Aegean Sea (Figure 1), a metamorphic core complex, capped by a flat detachment, is well exposed [Faure et al., 1991; Lee and Lister, 1992; Avigad et al., 1998; Skarpelis, 2002]. This detachment belongs to a larger, crustal-scale shallow-dipping extensional structure, the North Cycladic Detachment System (NCDS) [Jolivet et al., 2010] that runs all along the northern Cyclades. Based on field observations, this paper presents a detailed description of the geometry of the detachment on Mykonos and the structural evolution of its hanging wall and footwall. It further constrains the overall detachment kinematics and its initial shallow-dipping attitude. A crustalscale scenario of evolution of the detachment within the framework of the Aegean post-orogenic back-arc extension is finally proposed.

\section{Geological Setting}

[5] The Aegean Sea (Figure 1) results from back-arc extension and collapse of the Hellenic orogen above the northplunging subduction of the African slab since the Oligocene [Le Pichon and Angelier, 1979; Le Pichon, 1982; Jolivet et al., 1994; Gautier et al., 1999; Jolivet and Faccenna, 2000]. Migration of the volcanic arc suggests that extension started some 30-35 Ma ago and migrated southward [Jolivet and Brun, 2008] leading to the formation of a series of metamorphic core complexes [Bonneau and Kienast, 1982; Lister et al., 1984; Avigad and Garfunkel, 1989; 1991; Gautier and Brun, 1994a; Avigad et al., 1997; Ring et al., 1999].

[6] Extensional deformation following early tectonic burial has reworked the Hellenic nappe stack, leading to the widespread exposure of Eocene blueschists and eclogites. They were variably overprinted at greenschists to amphibolite-facies conditions during the Oligo-Miocene in the Cyclades [Altherr et al., 1982; Lister et al., 1984] and exhumed in the footwall of crustal-scale detachments. Three units are exposed in this area: (1) the Cycladic basement that crops out in the islands of Paros, Naxos, Mykonos, Delos and Ios. In some of these islands, an amphibolite-facies metamorphism associated with partial melting is dominant in the basement and dates back to the late Oligocene-early Miocene [Altherr et al., 1982]. (2) The Cycladic Blueschists, overlying the amphibolite-facies basement units, are made of several sub-units of metapelites, metabasites and marbles affected by Eocene eclogite to blueschist facies metamorphism and partially overprinted in HT-LP conditions during the Oligocene and Miocene [Altherr et al., 1979, 1982]. (3) The Upper Cycladic Nappe, made of serpentinites, gabbros and basalts, is the uppermost unit and has no manifestation of Eocene HP-LT metamorphism, nor of Oligo-Miocene HT-LP metamorphism [Dürr et al., 1978; Bonneau, 1982; Papanikolaou, 1987]. Some syn-tectonic
Miocene granites intrude this sequence [Lee and Lister, 1992; Altherr and Siebel, 2002]. Molassic sedimentary rock of Oligo-Miocene age are found on top of this edifice on a few islands such as Naxos, Paros and Mykonos.

[7] The tectonic contacts between the Upper Cycladic Nappe, the Cycladic Blueschists, and the Cycladic basement (including the granites) are made through detachments observed on the islands of Andros, Tinos, Mykonos, Ikaria, Paros and Naxos [Lister et al., 1984; Faure et al., 1991; Lee and Lister, 1992; Gautier et al., 1993; Gautier and Brun, 1994b; Ring et al., 2003; Mehl et al., 2005; Kumerics et al., 2005; Mehl et al., 2007; Brichau et al., 2006, 2007, 2008] (Figure 1). Except for the Naxos-Paros detachment, these islands belong to the North Cycladic Detachment System (NCDS), a crustal-scale structure separating the Cycladic Blueschist in the footwall from the Upper Cycladic Nappe in the hanging wall [Jolivet et al., 2010]. The NCDS is made of three more local detachments (Tinos detachment, Livada detachment and Mykonos detachment).

[8] Mykonos is a little island with a total surface of less than one hundred square-kilometers located in the central Aegean Sea at the southeast of Tinos Island. Mykonos is mostly made of an I-type monzogranite dated at around 10 13Ma [Voreadis, 1961; Altherr et al., 1982; Brichau et al., 2008] (Figure 2), slightly younger than the Tinos granite $(\sim 14 \mathrm{Ma})$. The granite is a kilometer-scale laccolith intruded into micaschists at the top of migmatitic gneisses belonging to the basement [Faure et al., 1991; Lucas, 1999] that crops out only in the islands of Delos and Rhinia (see location on Figure 2) and in the southwestern part of Mykonos island (Appolonium). The laccolith constitutes the core of an extensional gneiss dome and displays an intense magmatic deformation. It intruded the upper crust during the activity of the NCD and shows an intense mylonitization when approaching the detachment surface. A comparison with the neighboring islands where the NCDS crops out shows that the Tinos and Mykonos granites intruded both the Cycladic basement visible on Mykonos and the extensional contact (Tinos detachment) between the Cycladic Blueschists and the Upper Cycladic Nappe. The granites are then deformed by the activity of the Livada and Mykonos detachments that are well exposed in the northeastern part of Mykonos at Cape Evros, and along the western shore of Panormos Bay (Figures 2 and 3) [Voreadis, 1961; Faure et al., 1991; Lee and Lister, 1992; Avigad et al., 1998; Skarpelis, 2002]. The Livada detachment is mostly a ductile structure evolving to brittle that reactivates the intrusive contact between the granite and the metabasites (Upper Cycladic Nappe). The Mykonos detachment is a brittle structure that brings Miocene continental syn-rift deposits in contact with either the metabasites (at Cape Evros) or directly with the granite (at Panormos) (Figure 4). The association of the Livada and Mykonos detachments likely accommodated $\sim 30 \mathrm{~km}$ of

Figure 2. Geological map and cross-section (A-B) of Mykonos [see also Lucas, 1999] showing the detachment juxtaposing the main structural units of the island. The stretching lineation and the sense of shear are in agreement with previous works [Faure et al., 1991; Lee and Lister, 1992]. Red circles indicate the approximate location of samples for the paleomagnetic study [Morris and Anderson, 1996]. Cross-section C-D shows the geometry of the core of the Metamorphic Core Complex. 


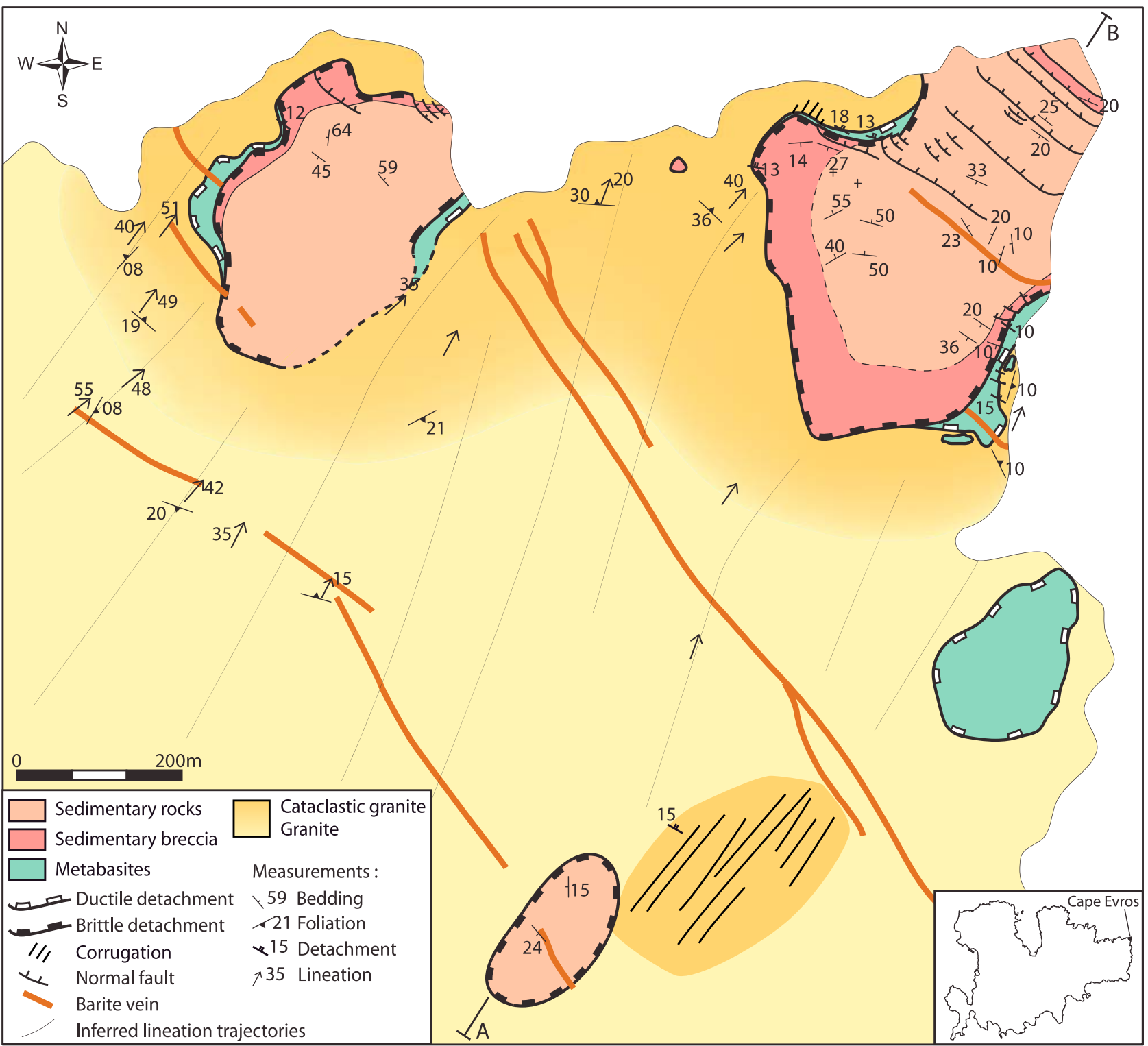

\section{A}

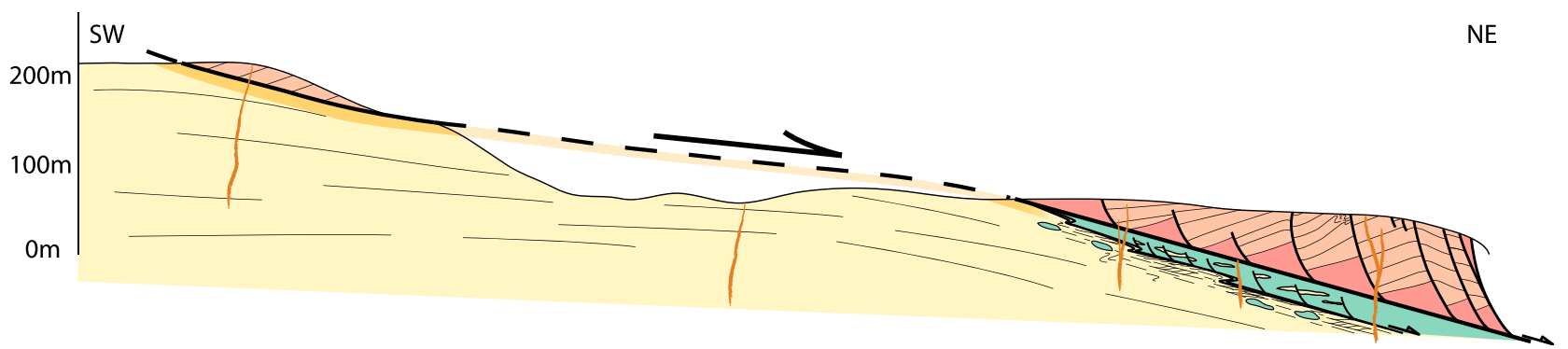

Figure 3. Detailed geological map and cross-section (A-B) of Cape Evros (NE of Mykonos) parallel to the stretching direction, showing the two branches of the detachment, the cataclasites, and the attitude of the sediments. 


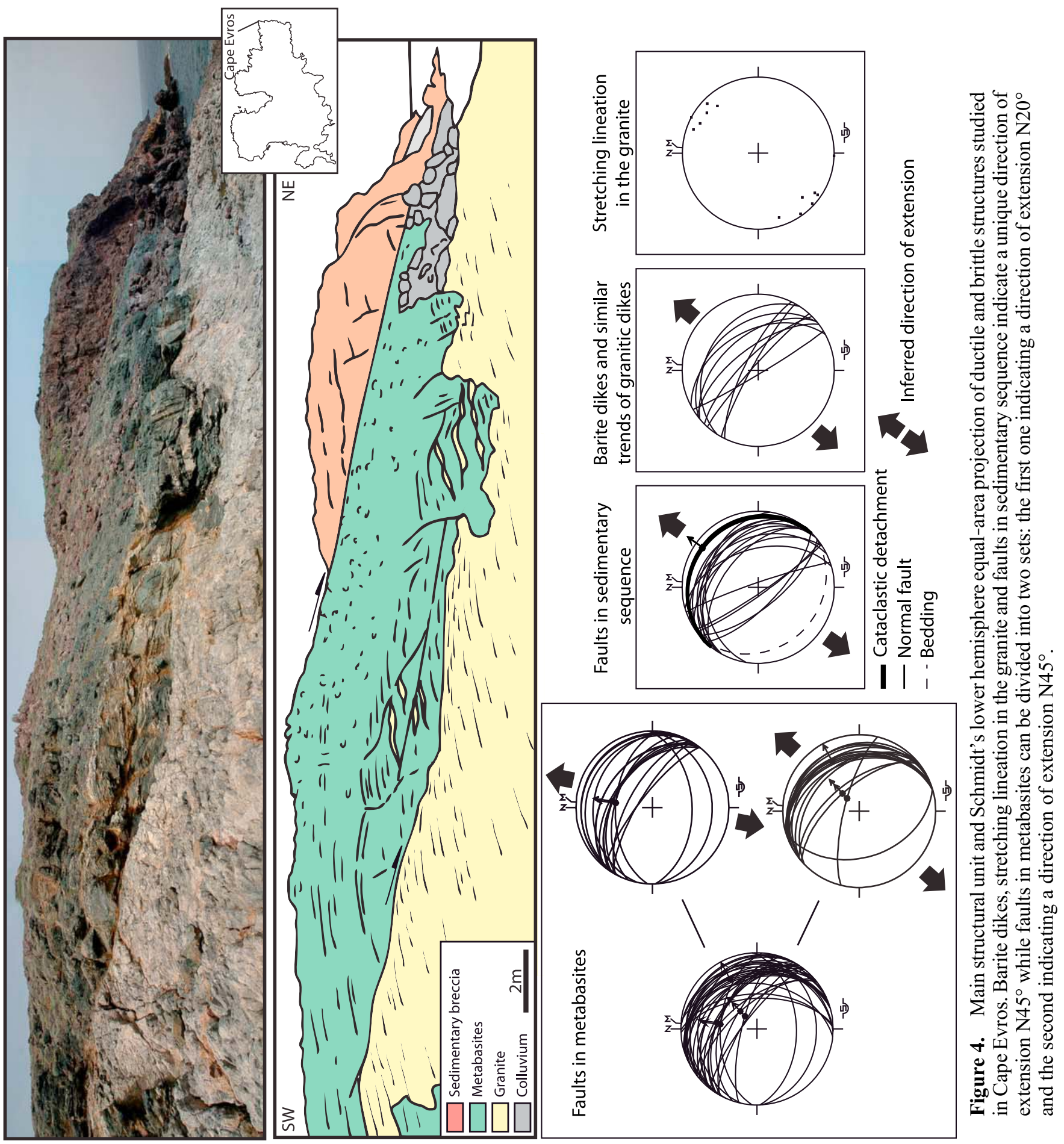



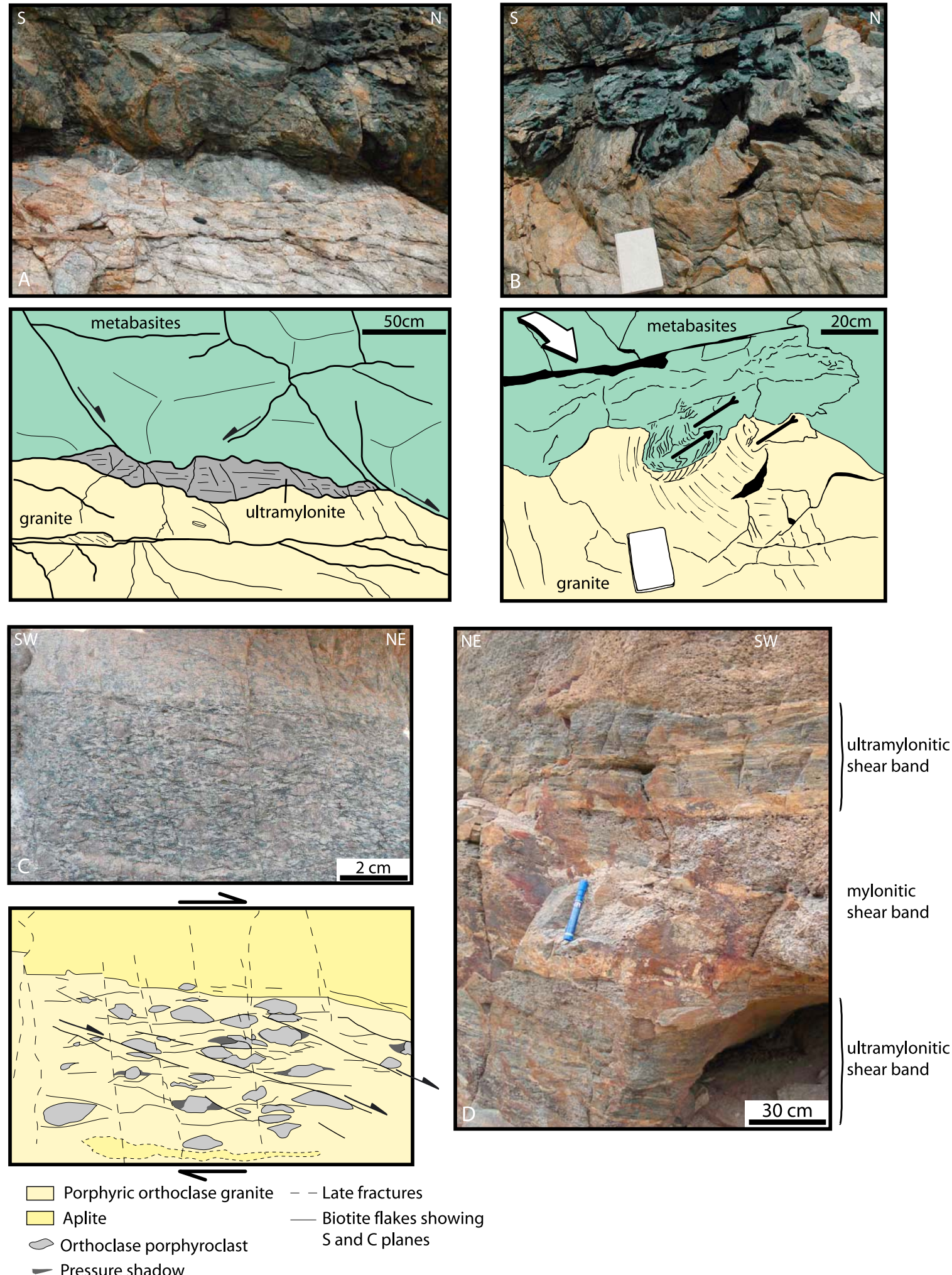

Figure 5. (a) Ultramylonitic shear band at the contact between the granite and the metabasites. (b) Asymmetric folds at the contact granite/metabasites. Fold axis (black arrows) are perpendicular to the NE sense of shear (white arrow). (c) Deformation of the granite in a plane parallel to the lineation (XZ plane). (d) Alternating mylonitic and ultramylonitic shear bands close to the detachment at Merchias. 

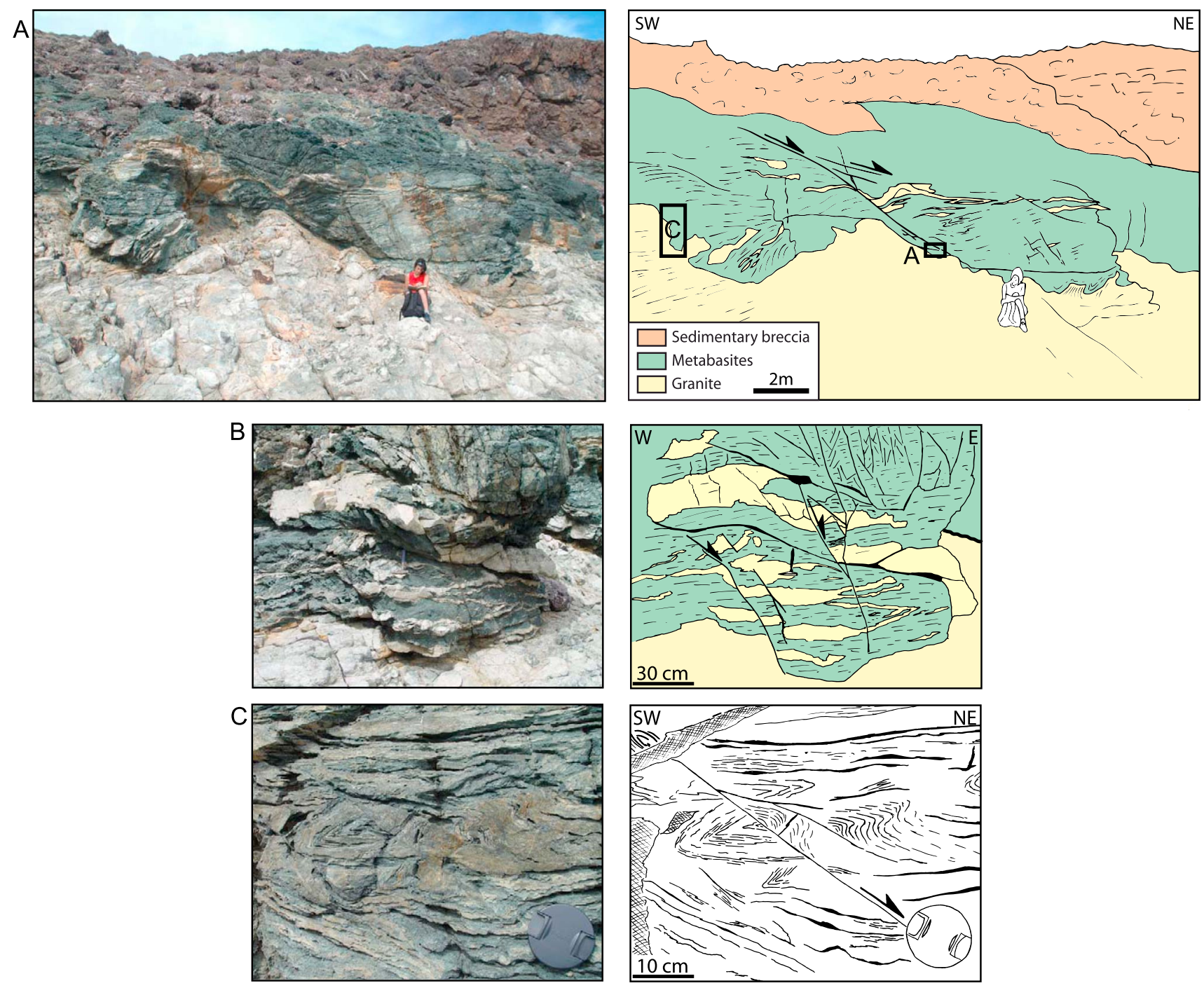

Figure 6. (a) A view of the brittle deformation of the metabasites. (b) Granitic sills cut by high-angle normal faults soling into the Livada detachment. (c) Fold within the metabasites close to the Livada detachment cut by a low-angle normal fault.

extension since the emplacement of the granite 13 Ma years ago [Brichau et al., 2008].

[9] The Panormos Bay corresponds to a young N-S trending graben which cuts through the granite and the metabasites (Figure 2). It is bounded by steep faults, oriented $\mathrm{N} 170^{\circ}$ to the east [Faure et al., 1991] and $\mathrm{N} 155^{\circ}$ to the west, that likely connect close to Elia (Figure 2). We describe our field observations in the following before a discussion of the kinematic evolution of the detachments.

\section{Structural Observations}

\subsection{Mykonos Granite}

[10] The Mykonos granite shows a variation of its mineralogy from a pyroxene-monzogranite in the southwest to a biotite-monzogranite in the northeast. The deformation evolves from protomylonitic close to the gneissic dome to ultramylonitic close to the detachment. The mylonitic fabric consists of a shallow-dipping foliation and a mineral lineation evolving into a stretching lineation toward the detachment. We observe a spatial rotation of the trend of the lineation in the granite from $\sim \mathrm{N} 70^{\circ}$ in the southwest to $\mathrm{N} 45^{\circ}$ in the northeast and $\mathrm{N} 20^{\circ}$ below the contact with the metabasites in the east.

[11] A strong shear strain gradient is observed in the granite toward the contact with the metabasites at Cape Evros. Across a few tens of meters a transition from an orthogneiss to a fine-grained mylonite and several bands of dark ultra-mylonites are observed (Figure 5d). The mylonitic fabric is characterized by a consistently NE-trending stretching lineation, carried by a well-developed shallowdipping foliation, defined by coarse and elongate quartz and feldspars grains, and aligned biotite and hornblende. Locally, the fabric shows a higher L/S ratio. The density of mylonitic and ultra-mylonitic shear bands, shallowly NEdipping, increases in the vicinity of the detachment (Figure 5d). 

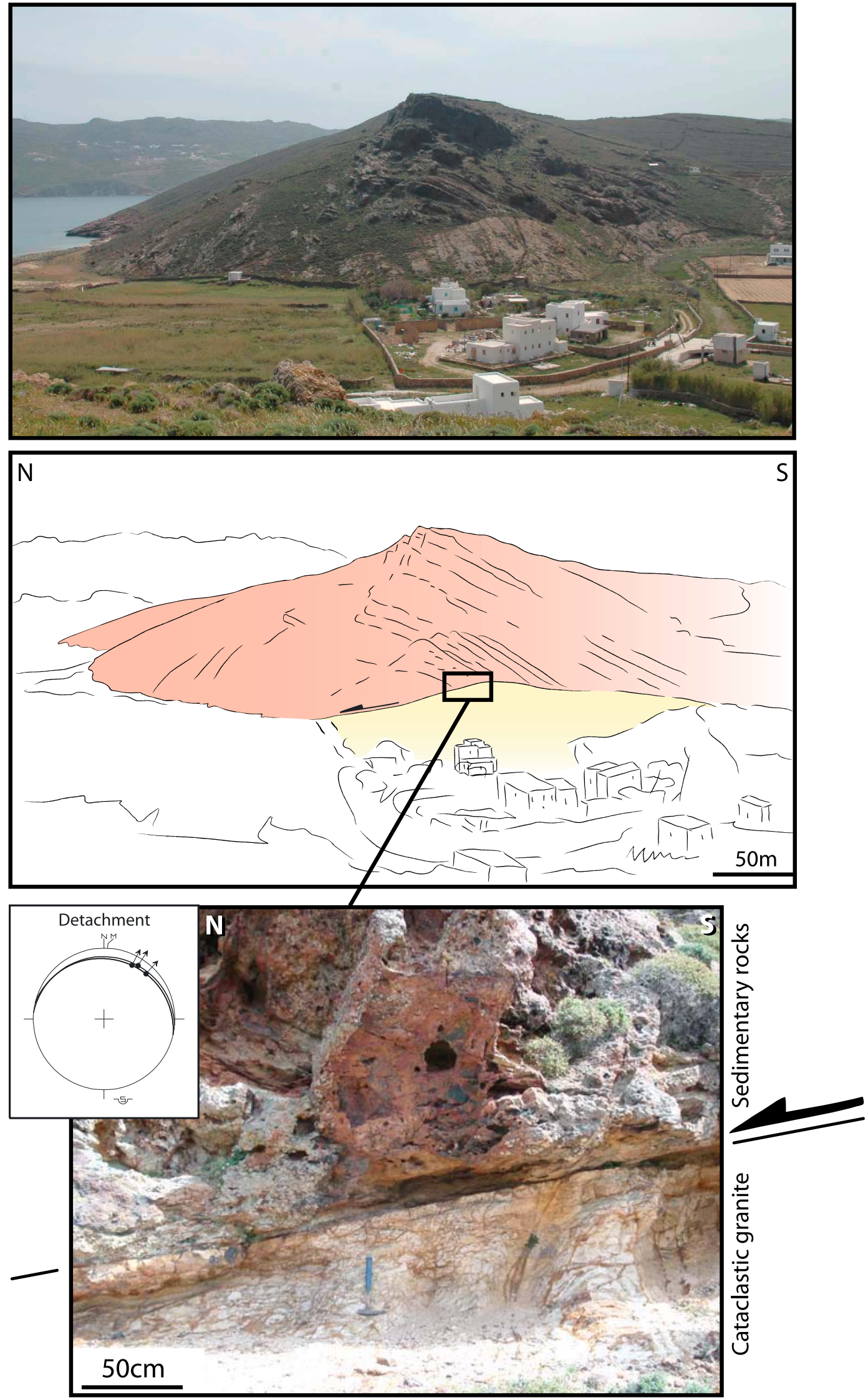

Figure 7

9 of 22 
Biotite flakes developed in shear planes make a small angle with the mylonitic foliation. Asymmetric pressure shadows on feldspar porphyroclasts are systematically observed, compatible with a top-to-the-NE shear sense (Figure 5c). The mylonitic foliation of the orthogneiss is folded when approaching the upper contact. Folds display an asymmetry consistent with a top-to-the-NE shear sense. All these structures indicate a progressive top-to-the-NE shear. They are cut by small subvertical steep faults oriented $\mathrm{N} 135^{\circ}$, indicating that extensional brittle deformation superimposed onto ductile deformation in the granite with the same stretching direction.

\subsection{Upper Cycladic Metabasites}

[12] The granite is overlain by greenschist-facies metabasites belonging to the Upper Cycladic Nappe. Metabasites have a variable thickness and crop out as small klippes in Cape Evros and near Merchias. The mylonitic foliation of the granite is locally deflected around rafts of metabasites enveloped within the granite. Aplitic sills and dikes $(10 \mathrm{~cm}-$ to $50 \mathrm{~cm}$-thick) are injected in the base of the metabasites, supporting intrusive relations of the granite within the metabasites (Figures 4 and 6). While poorly deformed in most of the upper unit, metabasites display an intense ductile deformation within a few meters above the contact with the granite (Figures 5 and 6). An intense foliation is parallel to the ultra-mylonitic foliation of the granite, and metabasites show folds similar to those found in the granitic mylonites below. Furthermore, the metabasites show an heterogeneous brittle deformation from the bottom to the top, overprinting the ductile deformation. Aplitic sills and dikes are cut or bounded by steep or shallow-dipping normal faults (Figure 6b) that display variable throws, from a few centimeters to several meters. These faults root into the contact with the granite and are consistent with a northeastward slip. Some of the shallow east dipping faults have offset the contact between the granite and the metabasites (Figure 6c). The orientation of the faults affecting the metabasite unit ranges between $\sim \mathrm{N} 90^{\circ}$ and $\sim \mathrm{N} 155^{\circ}$ with a dip evolving from $10^{\circ}$ to $80^{\circ}$ northeastward and striae indicating an northward or northeastward slip (Figure 4).

\subsection{Uppermost Molassic Sedimentary Sequence}

[13] An allochthonous sedimentary unit overlies the metabasite unit, or directly the granite where the metabasites are not preserved as in Panormos Bay (Figure 7). This unit has been interpreted as deposited in extensional basins formed in the upper crust during shearing at depth [Gautier and Brun, 1994b; Avigad et al., 2001]. This unit evolves from a 10meter-thick coarse silicified and mineralized sedimentary breccia near the detachment to a Miocene conglomerate and sandstone sequence [Dürr and Altherr, 1979; Sanchez-Gomez et al., 2002] (Figure 8). The latter consists of alternating pebbly, massive or layered sandstones and clast- to matrix-supported conglomerates. Clasts, sourced mainly from the Upper Cycladic Nappe, are rounded to subrounded and consist of reworked detrital clasts, greenish cherts, quartzite gneiss and volcanic clasts, found in the upper part of the conglomeratic sequence. The age of some volcanic clasts is about $10 \mathrm{Ma}$, which suggests that the sequence is younger than $10 \mathrm{Ma}$ [Sanchez-Gomez et al., 2002]. The whole unit displays a dark brown color, due to precipitation of Fe-hydroxides in sandstones and conglomerates [Skarpelis, 2002].

\subsection{Barite and Fe-Hydroxide Veins}

[14] Numerous sub-vertical barite and Fe-hydroxide veins cut through the upper part of the granite, the metabasites and the sedimentary rocks close to the detachment. On Cape Evros, the largest veins (several meters thick) are sub-vertical and display a $\sim \mathrm{N} 130^{\circ}$ orientation while secondary veins, connected to the main ones, are oriented $\mathrm{N} 120^{\circ}-\mathrm{N} 145^{\circ}$. In Panormos, few left-lateral small-scale strike-slip faults are associated with pull-aparts also filled with barite.

[15] In section 4 we describe the deformation related to the Livada and Mykonos detachments.

\section{Evidence for a Two-Branch Detachment System in Mykonos}

\subsection{Ductile-Then-Brittle Livada Detachment}

[16] The contact between the granite and the metabasite corresponds to a ductile shear zone dipping $15-18^{\circ}$ northeastward and oriented $\mathrm{N} 130^{\circ}$. It consists of a thin, folded ultra-mylonite (less than $20 \mathrm{~cm}$ thick) parallel to the granite mylonitic foliation (Figure 5a). Several other ultramylonitic shear zones are recognized within the deformed granite some $10-15 \mathrm{~m}$ below the contact (Figure $5 \mathrm{~d}$ ). Kinematic indicators within the mylonites and the ultramylonites show a top-to-the-NE shear sense. Folds are asymmetric with axes perpendicular to the lineation of the granite and parallel to the strike of the ductile shear zone (Figure 5b). They are also consistent with a northeastward displacement of the hanging wall. Locally, the granite-metabasite contact is reworked by brittle low-angle normal faults either localized on the top of the ultra-mylonitic band, or cutting through it, indicating a late brittle increment of extensional deformation with the same sense of motion (Figure 6).

[17] This detachment resembles the Livada detachment that crops out in the eastern part of the nearby Tinos island (see location on Figure 1). In this part of Tinos, the granite, intruding the metabasites of the Upper Cycladic Unit, is also ductilely deformed and shows a stretching lineation parallel to the direction of extension [Faure et al., 1991; Jolivet and Patriat, 1999; Brichau et al., 2007]. The intrusive contact is sheared and the base of the Upper Cycladic Unit is strongly foliated. As in Mykonos, brittle deformation is superimposed on shear and foliation planes and is compatible with the direction of regional extension [Mehl et al., 2005].

Figure 7. (top and middle) Shallow-dipping brittle contact separating the sedimentary sequence from the granite (Panormos Bay). (bottom) Zoom of the Mykonos detachment and Schmidt's lower hemisphere equal-area projection stereogram showing the geometry and the kinematic of the Mykonos detachment in this area. 

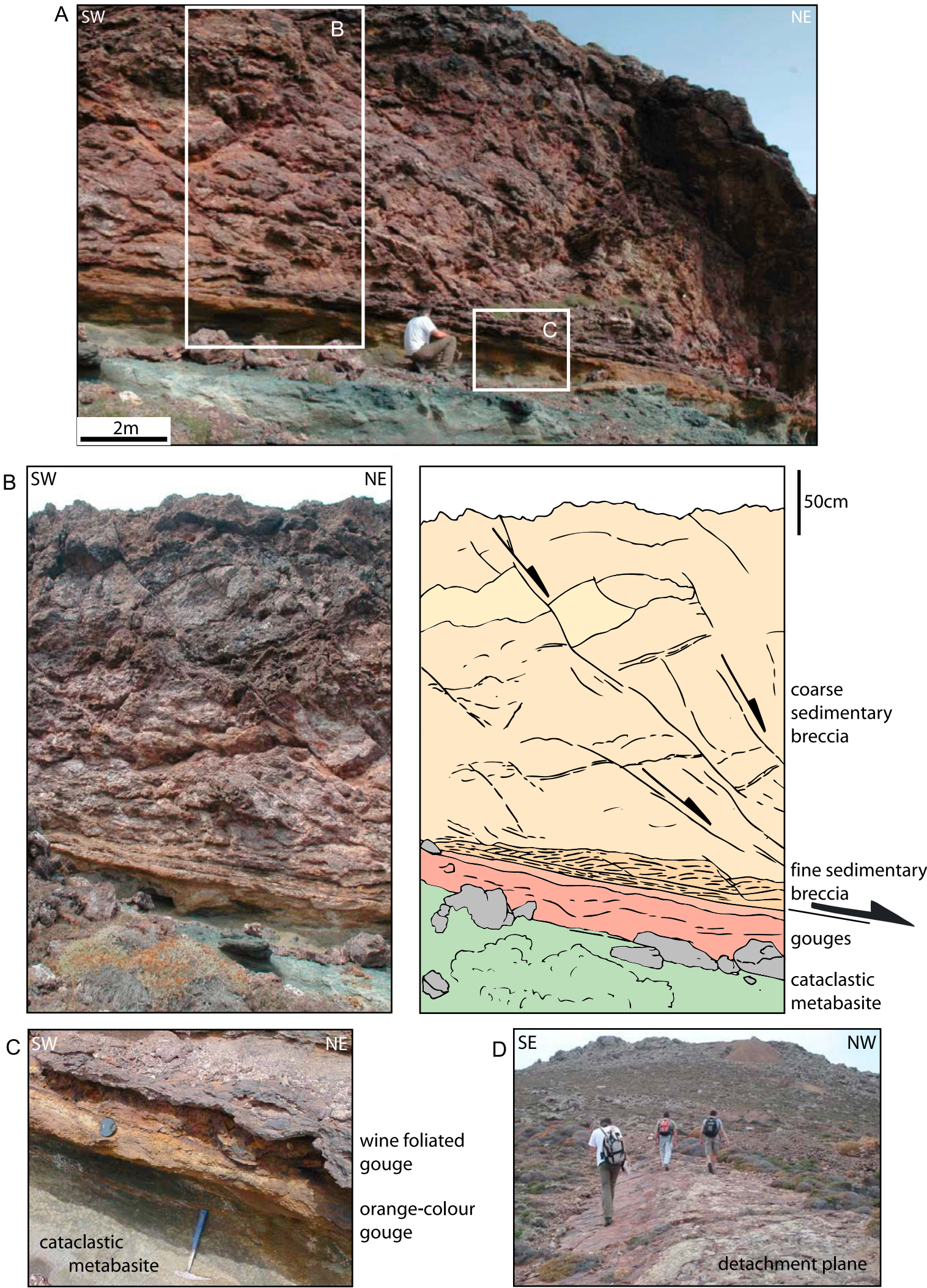

wine foliated gouge orange-colour gouge

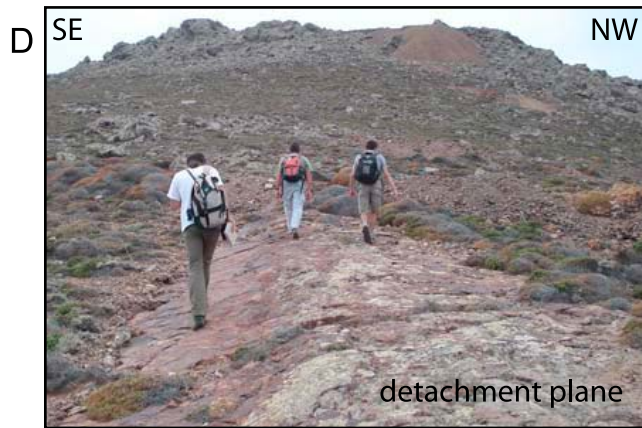

Figure 8. (a) The Mykonos detachment, a shallow-dipping brittle contact separating the sedimentary sequence from the metabasites at Cape Evros. (b and c) Zooms on the Mykonos detachment. Grey color represents colluviums. (d) Large-scale corrugation of the detachment, parallel to the northeastward slip direction. 
The ductile detachment of Mykonos is therefore similar geologically to the Livada detachment of Tinos, and evolved at the same time [Jolivet et al., 2010].

\subsection{Cataclastic-Brittle Mykonos Detachment}

[18] The top of the metabasites near Cape Evros is cut by a brittle cataclastic detachment. Within $2 \mathrm{~m}$ beneath the detachment, the Upper Cycladic Nappe is brecciated, forming cataclastic rocks. The density of the fractures/veins increases toward the detachment. Along the western shore of Panormos Bay, metabasites are not preserved and the brittle detachment juxtaposes the sedimentary unit directly over the granite which crops out as a sericitized cataclastic granite with a densification of veins and mineralization close to the contact. At the microscopic scale, the deformation is controlled by plastic processes. Quartz grains reveal undulatory extinction and recrystallization of quartz and feldspars grains into smaller grains is observed at grain boundaries.

[19] The detachment displays two different appearances depending on whether faulted and brecciated sedimentary rocks were transported directly on the top of the granite (as in Panormos Bay) or on top of metabasites (as in Cape Evros). In the first case, the detachment consists of a fault surface oriented $\mathrm{N} 100^{\circ}$, dipping $13-16^{\circ}$ northeastward (Figure 7), separating the cataclastic granite and the sedimentary unit with a thin gouge $(10 \mathrm{~cm})$ and a thin whitish layer of ultracataclasites. In the second case, when the detachment separates metabasites from the sedimentary unit (Figure 8b), the thickness of the cataclasites varies between $1 \mathrm{~m}$ to 4-5 $\mathrm{m}$. On the eastern coast of Cape Evros, the brecciated upper part of the metabasites is overlain by a $50 \mathrm{~cm}$ thick powdery orange-colored gouge passing upward to a foliated wine-colored gouge (Figure 8c). Shallow-dipping shear planes, with spacing of $10-20 \mathrm{~cm}$, cut the wine-colored gouge; foliation sigmoids in between indicate a top-tothe-NE shear sense. Three to four thinner layers of winecolored gouge are found within the intensely brecciated sedimentary rocks lying above. The detachment surface cuts through the orange-colored gouge and is oriented $\mathrm{N} 130^{\circ}$, $12^{\circ} \mathrm{NE}$. On the western coast of Cape Evros, the cataclasites are thicker and stratified. At the base they are mostly made of angular metabasite clasts and they evolve upward to a massive layer containing partly rounded clasts. On a nearby hill (south of detailed map, Figure 3), the metabasites are absent and the cataclasites rest directly on top of the granite forming a several meters thick layer. The cataclasites are made of mixture of a white granitic cataclasites containing angular clasts of metabasites. When the detachment plane crops out, it shows an intense striation parallel to the stretching lineation in the underlying mylonites and a $10-\mathrm{m}$ scale corrugation parallel to the northeastward slip direction and dip-slip striae (Figure 8d).

[20] Summarizing, the detachment on Mykonos is clearly divided in two branches: the lower branch (called the Livada detachment, as in Tinos), ductile and then brittle, shears the top of the granite, and juxtaposes metabasites over the granite. The upper branch (called the Mykonos detachment), brittle, separates metabasites from a late Miocene sedi- mentary unit (Figures 3 and 4). As discussed later, these two branches may have, at least partially, worked coevally at different crustal levels.

\section{Extensional Brittle Deformation of the Molassic Sequence and the Metabasites}

[21] The uppermost sedimentary unit displays evidence for internal deformation. Stratification dips toward the detachment plane and evidence for roll-over structures are found at Panormos (Figure 9) and, locally, at Cape Evros. At Panormos, the dip of stratification evolves from 30 to $40^{\circ}$ southwestward close to the detachment to sub-horizontal or northeastward moving away. We may interpret this in terms of a flat and ramp geometry of the shallow-dipping detachment (Figure 9). This would thus suggest a rather small displacement during the deposition of the sedimentary sequence. However, no outcrop continuity exists between the Panormos and the Cape Evros sedimentary rocks, so the Panormos rocks, which are the westernmost ones above the east-dipping detachment, could represent the youngest syn-rift sediments and thus could correspond only to the very end of the detachment activity.

[22] In Cape Evros, the metabasites display faults ranging in strike between $\sim \mathrm{N} 90^{\circ}$ and $\sim \mathrm{N} 155^{\circ}$ and associated with striae oriented $\mathrm{N} 20^{\circ}$ or $\mathrm{N} 45^{\circ}$. As shown in Figure 4, these faults can be divided into two sets: one set corresponds to faults oriented in a range between $\sim \mathrm{N} 90^{\circ}$ and $\sim \mathrm{N} 125^{\circ}$ associated with striae oriented $\mathrm{N} 20^{\circ}$; the other set comprises faults oriented $\mathrm{N} 125^{\circ}-\mathrm{N} 155^{\circ}$ with striae oriented $\mathrm{N} 45^{\circ}$. Unfortunately, the different lithologies (metabasites, cataclasites, breccia and coarse molassic sedimentary rocks) and the effects of barite and Fe-hydroxide fluid circulation did not allow a good preservation of striae on faults. Thus, these structures do not enable a calculation of a well-constrained stress tensor. Nevertheless, the $\mathrm{N} 90^{\circ}-125^{\circ}$ set is compatible with a $\mathrm{N}-\mathrm{S}$ to $\mathrm{N} 20^{\circ}$ direction of extension whereas the $\mathrm{N} 125^{\circ}-155^{\circ}$ set is rather consistent with a NE-SW extensional trend. The latter is also compatible with the strike of barite and granitic sills intruding the metabasite unit (Figure 4). The overlying sedimentary unit is also cut by numerous steep faults, soling into the basal gouges and cataclasites with an orientation ranged from $\sim \mathrm{N} 125^{\circ}$ to $\sim \mathrm{N} 155^{\circ}$. The largest faults are regularly spaced and define a tilted-block geometry (Figure 3). Faults dip mainly $30^{\circ}$ to $60^{\circ}$ northeastward but some faults dipping $70-80^{\circ}$ southwestward are also observed. When bedding at Cape Evros (strike $130^{\circ} \mathrm{E}$, dip $20^{\circ} \mathrm{SW}$ ) is stereographically rotated back to horizontal by rotation around the local strike by the amount of dip, the faults have a mean $\mathrm{N} 130^{\circ}$ orientation with a dip ranging between $50^{\circ}$ and $80^{\circ}$ northeastward or southwestward. This reconstruction is consistent with a subvertical maximal principal stress, $\sigma_{1}$, and a sub-horizontal minimal principal stress, $\sigma_{3}$, oriented $\mathrm{N} 45^{\circ}$. Again, striations on faults are too scarce to calculate a stress tensor but their orientation is consistent with the orientation of the brittle detachment oriented $\mathrm{N} 130^{\circ}, 12^{\circ} \mathrm{NE}$ with dip-slip striae oriented $\mathrm{N} 40^{\circ}$. 


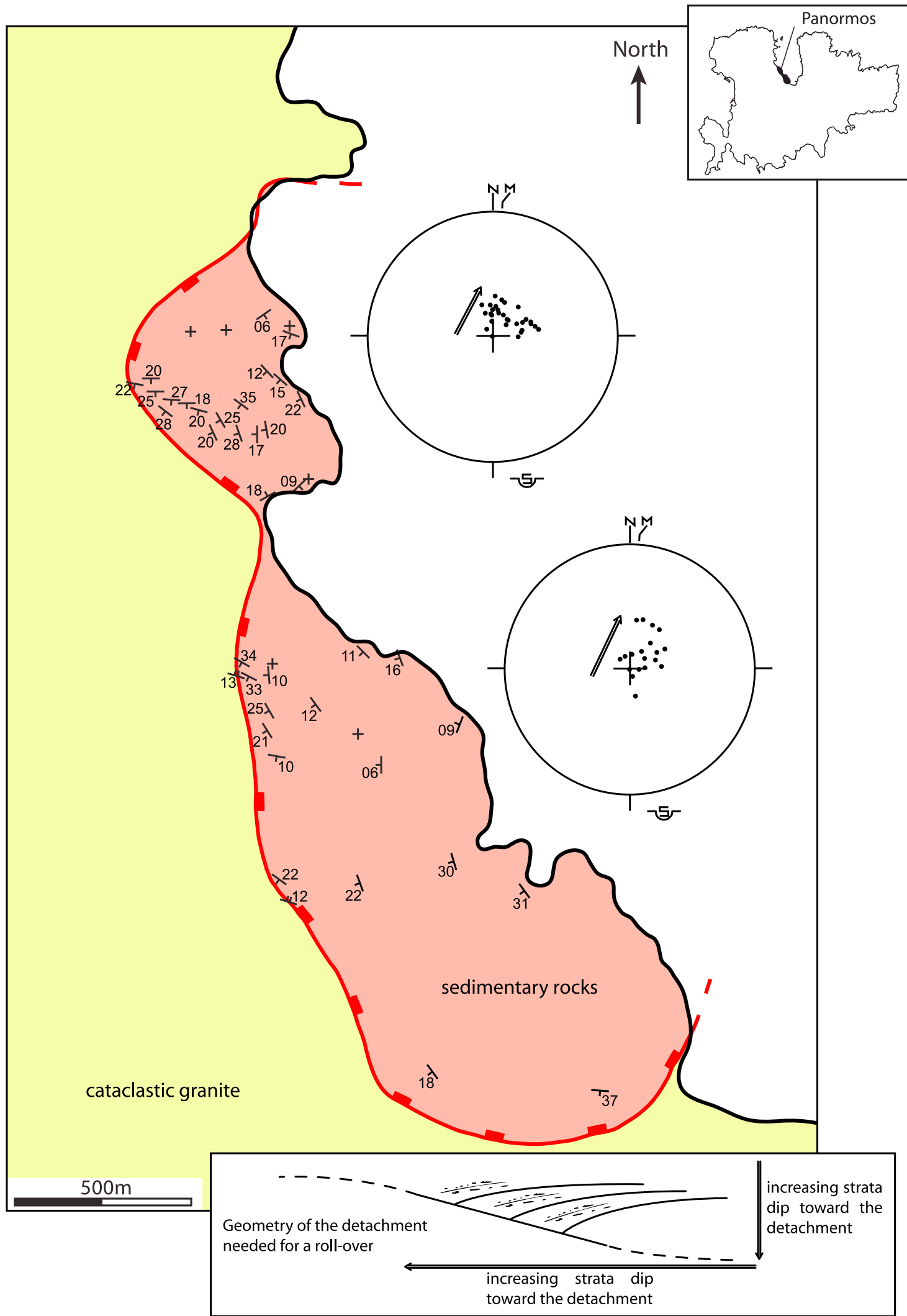

Figure 9. Detailed geological map of Panormos Bay and Schmidt's lower hemisphere equal-area projection of the poles of the bedding showing an evolution of the strata dip toward the detachment (black arrow) suggesting a local roll-over structure. 
A
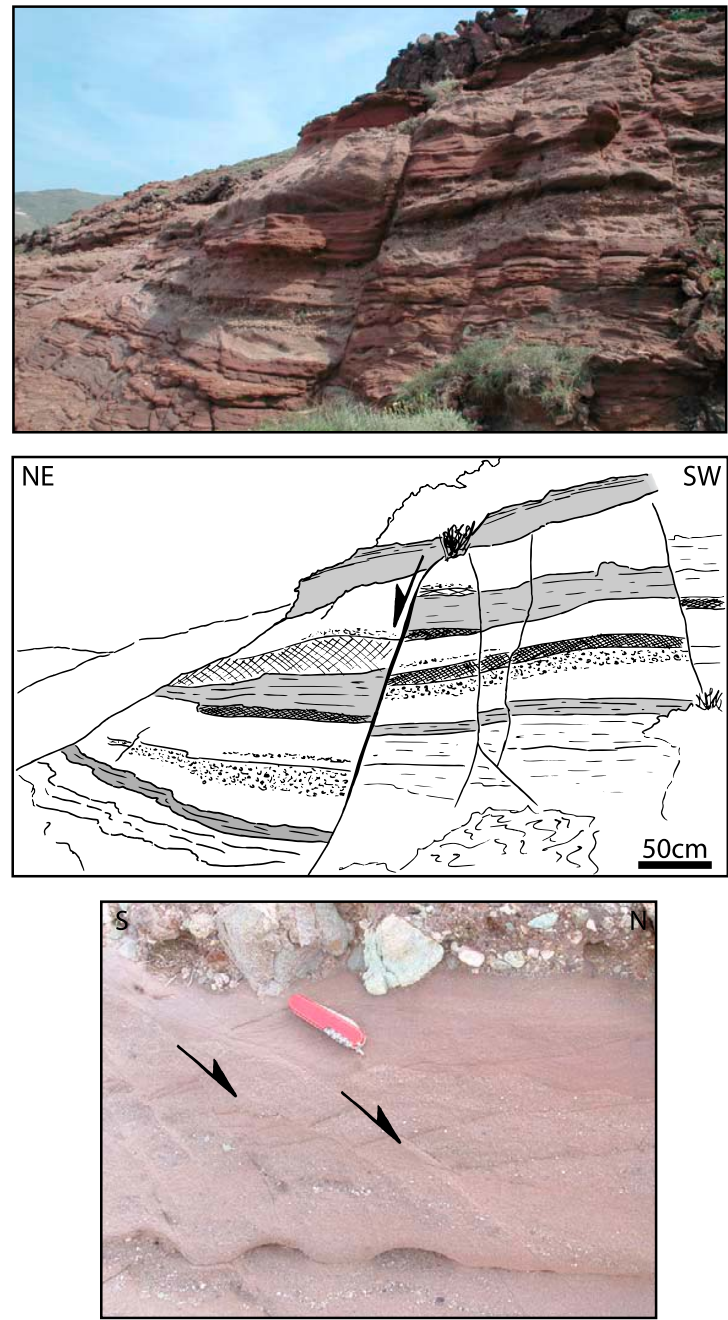

B

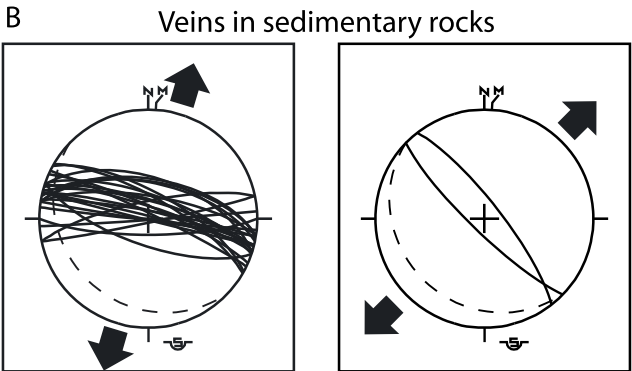

Normal faults in sedimentary rocks
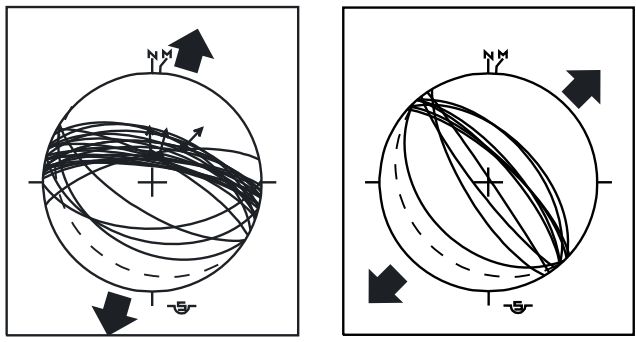

Strike-slip faults in sedimentary rocks
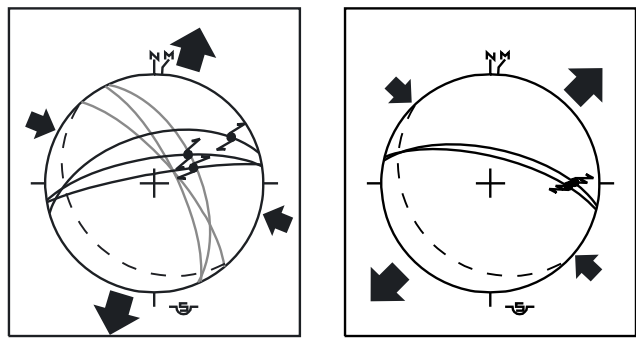

— Left-lateral strike slip faults (sense inferred from barite-filled small pull-aparts)

- - Bedding

Inferred direction of extension

Figure 10. (a) High-angle normal fault in Panormos Bay showing bed thickness variations on both sides of the fault, with greater bed thickness in the hanging wall and suggesting syn-depositional normal faulting. (b) Schmidt's lower hemisphere equal-area projection of veins, normal and strike-slip faults observed in Panomos Bay suggesting either two successive directions of extension (N20 then $\mathrm{N} 45^{\circ}$ ) or a clockwise rotation of structures about a vertical axis under a single $\mathrm{N} 20^{\circ}$ regional extension (see text).

[23] In Panormos Bay, the conglomeratic sequence displays a more complex network of small-scale brittle structures composed of veins, normal faults and strike-slip faults (Figure 10b). As in the metabasites in Cape Evros, veins and faults can be divided into two sets. The first population of faults and veins has an orientation between $\mathrm{N} 120^{\circ}$ and $\mathrm{N} 155^{\circ}$. Faults of this family have throws that range from a few centimeters to several meters; bed thickness variations on both sides of the fault, with greater bed thickness in the hanging wall (Figure 10a) suggest syn-depositional normal faulting. Faults dip principally $60-80^{\circ}$ northeastward with kinematics compatible with $\mathrm{N} 45^{\circ}$ extension. The second set corresponds to faults and veins with an orientation ranging between $\mathrm{N} 80^{\circ}$ and $\mathrm{N} 120^{\circ}$. This arrangement is consistent with $\mathrm{N}-\mathrm{S}$ to $\mathrm{N} 20^{\circ}$ extension (Figure $10 \mathrm{~b}$ ). Veins dip mostly to the NE close to $70-80^{\circ}$ but sedimentary rocks affected by these veins are globally oriented $\mathrm{N} 130^{\circ}$ and tilted $20^{\circ}$ southwestward (Figure 9). If bedding is back-rotated to horizontal, veins become sub-vertical with an average $\mathrm{N} 110^{\circ}$ trend. Some small-scale strike-slip faults are also observed: sinistral strike-slip faults are oriented $\mathrm{N} 140^{\circ}$ and are associated with pull-aparts filled with barite; dextral strike-slip faults are oriented $\mathrm{N} 80^{\circ}$ to $\mathrm{N} 110^{\circ}$; both are kinematically consistent with a $\mathrm{N} 20^{\circ} / \mathrm{N} 50^{\circ}$ trending minimum principal stress (Figure 10b).

[24] As a result, in Mykonos, brittle deformation is accommodated by two sets of structures (faults and veins) affecting the metabasites and the sedimentary unit. The first set of faults and veins, formed during deposition of the molassic sequence, is mainly oriented $\mathrm{N} 135^{\circ}$ and is consistent with a NE-SW direction of extension. The second one is oriented $110^{\circ}$ and is associated with N20 $0^{\circ}$ striae. All 
structures were secondarily tilted southwestward as shown by the dip of the sedimentary rocks. The two sets of structures point toward two directions of extension, which may be explained either by a rotation of the regional direction of extension or by the rotation of the structures within a single regional extensional stress field. As discussed below, several arguments support instead a single direction of extension and a rotation of early formed structures.

\section{Evidence for Slip With Shallow Dip and at Shallow Depth Along the Cataclastic-Brittle Mykonos Detachment}

\subsection{Evidence for Slip At Shallow Dip}

[25] The direction of the main sub-vertical barite veins, perpendicular to the slip direction and to the direction of ductile shear in the granite, shows that they were produced in the same continuum of NE-SW extension (Figure 4). Veins in general cut all units from the upper part of the granite to the top of the sedimentary rocks, but some of them are cut by the brittle detachment or have penetrated the sedimentary breccia and are sealed within the conglomeratic sequence. These facts support the hypothesis that the veins have formed during intense perigranitic fluid circulation while the brittle detachment was still active. Moreover, fanshaped deposits, observed at Cape Evros, are made of sandstones and bounded by steep faults (Figure 11). The dip of strata evolves from $30^{\circ} \mathrm{SW}$ at the base to sub-horizontal on the top of the fans. A thin sub-horizontal sedimentary layer overlies fan-shaped deposits, which suggests that no significant post-slip tilt of the whole structure has occurred, making the Mykonos detachment similar to other structures described in the Basin and Range province such as the Sevier Desert detachment or the Mormon Peak detachment [Wernicke et al., 1985]. In addition to small-scale fracture analysis that supports a sub-vertical attitude of the maximum principal stress, that therefore lies at high angle to the detachment plane, this implies that the brittle cataclastic detachment was active with a very shallow dip close to its current position.

\subsection{Evidence for Slip at Shallow Depth}

[26] Soft-sediment deformation is observed in the hanging wall of normal faults or close to the detachment (Figures 11 and 12). Besides fan-shaped deposits mentioned above, slumps, composed of more or less indurated sandstones, can be observed in half-grabens whose boundary faults cut the sedimentary breccia (Figure 12). Slumps are bounded by steeply dipping faults soling into the brittle detachment. Slump fold axes are consistent with a northeastward displacement of the hanging wall (Figure 12b). The slumped sediments are stretched, boudinaged, folded and displaced by steep normal faults into contact with the basal cataclasites. The soft-sediment deformation is locally intense and we found no compelling evidence of liquefaction that would suggest instabilities related to earthquakes; the observed deformation seems more related to a long-term deformation induced by stretching of the basin above the detachment. The coarse breccia at the base of the sedimentary rocks is sometimes totally removed by faulting and the slumped sediments rest directly on top of the striated detachment plane (Figure 12).

[27] Although the formation of the cataclasites occurred certainly at deeper levels, sedimentary thickness variations and slumps associated with steep normal faults rooting in the detachment support an overall syn-depositional kinematics of the detachment at a very shallow crustal level, close to the surface.

\section{Discussion}

7.1. Rotation About a Vertical Axis of Footwall Granite and Hanging Wall Metabasites and/or Sedimentary Unit During Extension

[28] As mentioned above, the mylonitic fabric of the granite comprises a consistent NE-trending stretching lineation. The strike of the lineation rotates progressively northeastward to become more northerly oriented immediately below the detachment (Figure 2). This rotation shown by the lineation in the granite is at first glance compatible with the $22^{\circ}$ clockwise rotation measured by paleomagnetism [Morris and Anderson, 1996] but its magnitude is larger. The paleomagnetic rotation had previously been interpreted as a late rotation of the whole island after the rocks have been exhumed above the brittle-ductile transition suggesting that the direction of shear had to be restored and back rotated by the same amount. However, sampling for paleomagnetic measurements was made in the least deformed part of the granite and thus far from the detachment (see Figure 2 for the location of the samples). In addition to the observation of the rotation of lineation, this may indicate that only the more rigid core of the granite underwent rotation during extension (and not after) in a general top-to-the-NE simple shear extensional regime. The true direction of extension would thus be that of the lineations observed immediately below the detachment (i.e., $\mathrm{N} 20^{\circ}$ ). This would not change the true direction of extension $\left(\mathrm{N} 20^{\circ}\right)$ compared to the interpretation of Morris and Anderson [1996], but it would imply that the rotation concerned only the less deformed part of the granite. This interpretation is probably not unique, as a change in the regional direction of extension is always possible. However, it seems to reconcile structural observations and paleomagnetic measurements in a first approach. Moreover, it is consistent with previous studies showing a rotation of the Aegean region under a single N20 -directed regional extension [e.g., Van Hinsbergen et al., 2005; Walcott and White, 1998], contrary to an alternative interpretation that would imply a change in the regional direction of extension.

[29] Brittle microstructures in sedimentary rocks and metabasites indicate two apparent directions of extension (section 5): the first $\mathrm{N} 45^{\circ}$, syn-depositional, and the second one $\mathrm{N} 20^{\circ}$. We propose that these two extensional trends result from the $25^{\circ}$ clockwise passive rotation of sedimentary rocks and metabasites during extension as suggested above for the granite by paleomagnetic measurements. The entire deformation observed in Mykonos could thus be simply explained by a single direction of extension $\mathrm{N} 20^{\circ}$ and a $22-25^{\circ}$ clockwise rotation of the system during extension. If this scenario is correct, the oldest $\mathrm{N} 130^{\circ}$ 

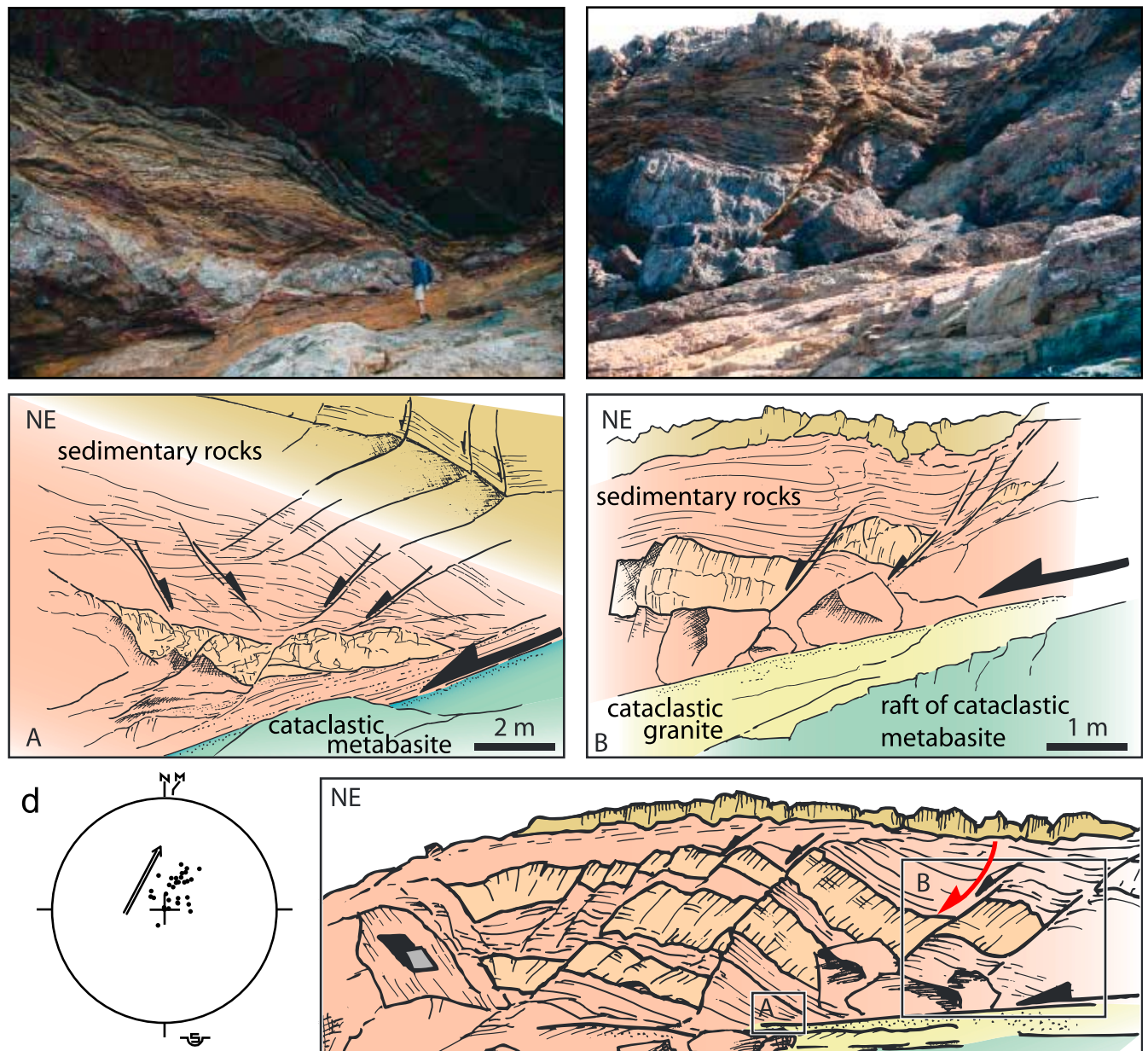

The arrow indicates the

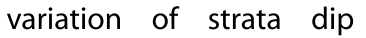
toward the detachment
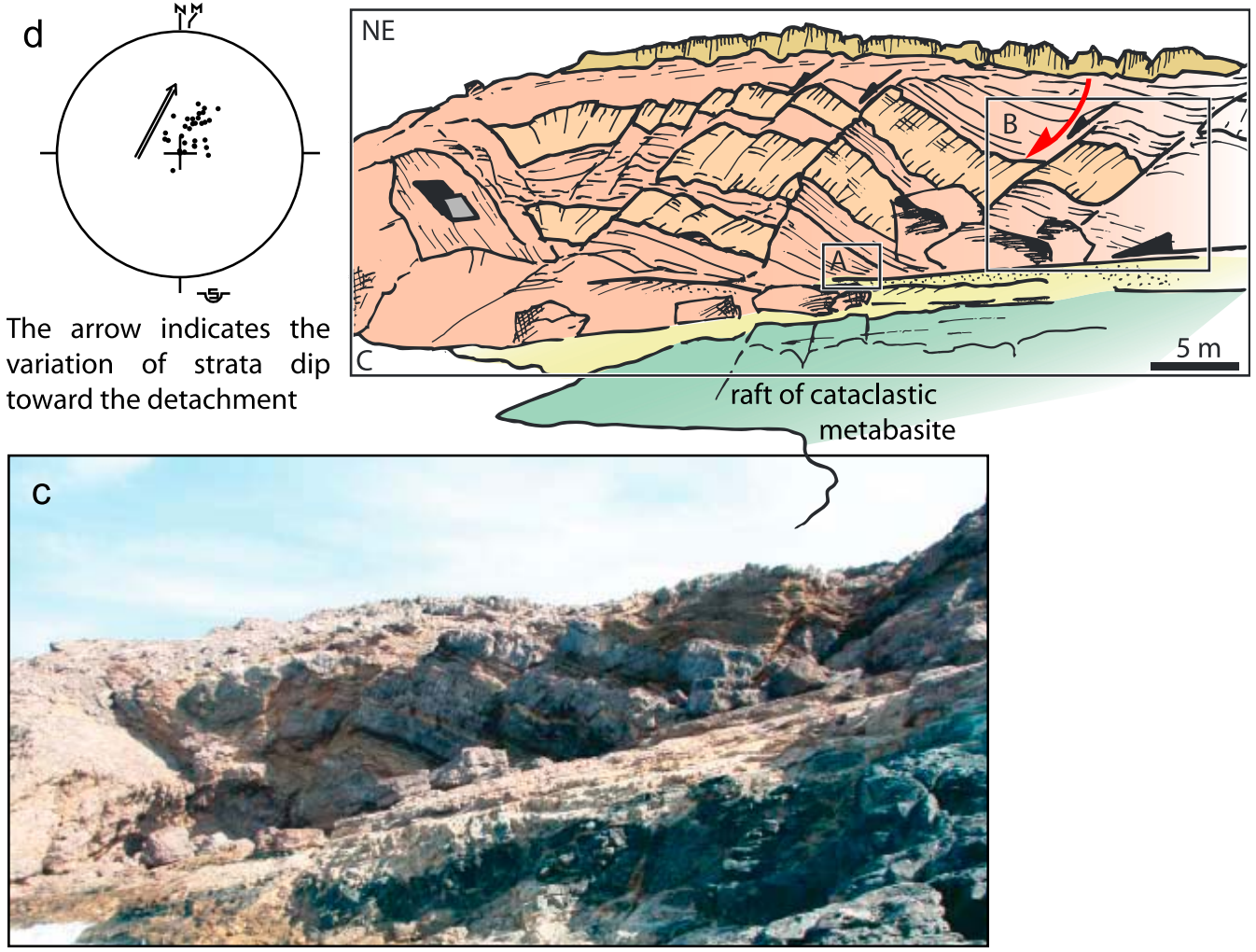

Figure 11. Deformation of the sedimentary unit showing fan-shaped deposits (red arrow) in Cape Evros bounded by steep normal faults soling into the detachment. Schmidt's lower hemisphere equal-area projection stereogram of poles of the strata indicates an increase of the bedding dip toward the Mykonos detachment (black arrow on the stereograph). 

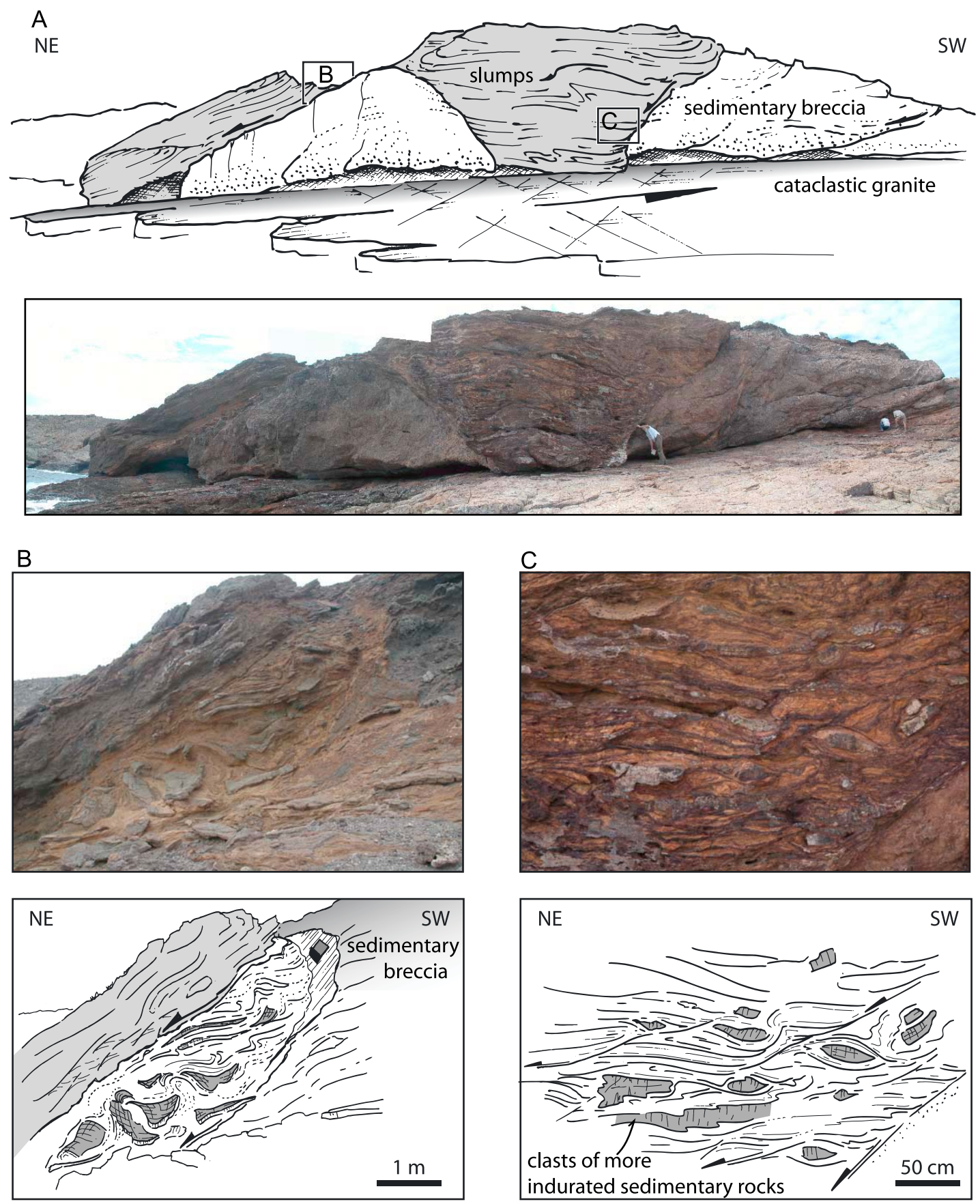

Figure 12. (a) Slumps observed within half-grabens cutting the sedimentary breccia in Cape Evros. Steep normal faults bounding the slumps root into the Mykonos detachment. (b and c) Zoom on slumps, made of more or less indurated sandstones, showing their internal structures.

faults (which are syn-depositional) were initially oriented $\mathrm{N} 110^{\circ}$ and were secondarily rotated passively while new $\mathrm{N} 110^{\circ}$ faults and veins developed.

[30] The rotation of $20-25^{\circ}$ about a vertical axis of both the footwall and the hanging wall of the Mykonos detachment implies a rotation of the Mykonos detachment itself. A single brittle detachment is however observed, which suggests that extension was accommodated by the same shallow- dipping structure, that remained active during the rotation. The direction of slip along the detachment plane was likely continuously "reset" to $\mathrm{N} 20^{\circ}$, so that most expected oblique striations on the detachment plane that would have recorded the rotation are absent or are hardly observed. Striations measured on the detachment plane in Panormos, ranging from $\mathrm{N} 20^{\circ}$ to $\mathrm{N} 40^{\circ}$ in azimuth (Figure 7), seem however to support this scenario. 
[31] Finally, the sedimentary unit at Panormos was tilted to $30^{\circ}$ southwestward in the last increment of deformation during the formation of a local roll-over structure.

\subsection{Has the Whole Mykonos Island Rotated About a Horizontal Axis?}

[32] Avigad et al. [1998], arguing on earlier paleomagnetic measurements in the granite [Morris and Anderson, 1996] (see Figure 2 for the location of the samples), also suggest a rotation of the whole island of $24^{\circ} \mathrm{SW}$-ward about an horizontal axis (tilting) followed by the above mentioned clockwise rotation for both Tinos and Mykonos. Tilting must have occurred before the formation of the large vertical barite veins that mostly postdate slip along the detachment [Avigad et al., 1998]. The observation that these veins share the same vertical attitude and the same strike as Miocene dacitic dikes on Tinos led these authors to conclude that they were formed in the same stress field in the Miocene. The similar strike suggest that they have been affected by the same clockwise rotation as the dikes on Tinos and thus that vertical axis rotation postdated tilting (section 7.1). Avigad et al. [1998] thus consider the horizontal and vertical components of the rotation separately and they conclude to an early tilting of the whole island by some $24^{\circ}$ toward the SW. This interpretation is clearly inconsistent with field observations indicating a shallow dip of the detachment during the last stage of brittle slip (section 6.1). The ductile mylonitic foliation is shallow-dipping and roughly parallel to the brittle detachment. Assuming a steeper detachment would imply a steeper mylonitic foliation before the overall tilting around a horizontal axis as discussed by Avigad et al. [1998]. The extensional shear zone and the detachment would have started as classically steeply dipping structures, then they would have been tilted and only the last stage of slip along the brittle detachment would have occurred with a shallow dip before the whole system was later cut by vertical barite veins, which is a first possible interpretation. The samples measured for paleomagnetism by Morris and Anderson [1996] were however taken as to avoid the deformed part of the granite (Figure 2) and thus they cannot constrain the initial attitude of the detachment-related mylonite enveloping the intrusion or the attitude of the fault itself, which may offer a way to reconcile paleomagnetic measurements and the geometrical characteristics of the detachment. Syn-rift sediments on Mykonos have been proven to be younger than $10 \mathrm{Ma}$ as they include volcanic clasts of that age [Sanchez-Gomez et al., 2002]. Tilting on Mykonos must then have occurred before $10 \mathrm{Ma}$ if one considers that the whole granite and the mylonite have been affected and clockwise vertical-axis rotation on both Tinos and Mykonos must have occurred after $10 \mathrm{Ma}$. The duration left for tilting after the intrusion of the granite at $13 \mathrm{Ma}$ [Brichau et al., 2008] and before $10 \mathrm{Ma}$ is thus very short. We propose alternatively that the rotation, identified through paleomagnetic measurements in the least deformed part of the granite (i.e., away from the detachment), rather reflects the southwestward rotation of the rigid part of the granite during extensional shearing and does not affect the brittle detachment itself. The scenario is thus as follows: the ductile
Livada detachment leading to the formation of the thick mylonite at the top of the pluton started as a shallowdipping structure. During top-to-the-NE shearing, the less deformed part of the granite was tilted by rotation about an horizontal axis, explaining inclination data. The brittle Mykonos detachment formed in the same continuum of extension and exhumation as a shallow-dipping structure and syn-rift sediments were deposited in the hanging wall. Finally, during the latest stages of extension vertical barite veins intruded the granite, the detachment and the sedimentary sequence. It thus comes that at least the brittle slip on the Mykonos detachment occurred while it was at shallow dip and that paleomagnetic constrained rotation of the footwall granite does not require a steeper dip of the detachment.

\subsection{Estimation of the Exhumation of the Footwall}

[33] Even if it is difficult to quantify the amount of the extension accommodated by each branch of the detachment, the exhumation of the footwall can be estimated. Based on fission track analysis and (U-Th)He dating on zircons and apatites, Brichau et al. [2008] calculated an average slip rate of the detachment system of $6.0+9.2 /-2.4 \mathrm{~km} / \mathrm{Ma}$ during the granite emplacement from 14 to $9 \mathrm{Ma}$, leading to a total displacement bracketed between 12 and $45 \mathrm{~km}$ along the slip direction. Estimating the dip of the detachment to $30^{\circ}$, they proposed $15 \mathrm{~km}$ of exhumation of the footwall of the Mykonos detachment at an average exhumation rate of $3 \mathrm{~km} / \mathrm{Ma}$. However, field observations suggest that the brittle motion along the detachments occurred at very shallow dip without significant rotation of the whole structure. Moreover the Mykonos (brittle) and Livada (ductile) detachments are part of a larger detachment system (the NCDS) cropping out from Andros to Mykonos at least [Jolivet et al., 2010]. This detachment forms the contact between the Cycladic Blueschists (not visible in Mykonos) and the Upper Cycladic Nappe (mainly metabasites and serpentinite, equivalent of the metabasite unit of Mykonos). The NCDS has everywhere a shallow dip and structural observations in the footwall suggest that it was initiated with a shallow dip [Mehl et al., 2005]. The Cycladic Blueschists rest above the Cycladic basement that is exhumed on Mykonos in the core of the gneiss dome. As the deepest unit has been brought into close contact with the uppermost one in Mykonos, the total displacement along the detachment system has been larger than in other islands. This must however be tempered by the lack of knowledge on the initial geometry, although it is likely that the detachment was initiated as a shallowdipping structure in Mykonos as in other regions of the NCDS. Using the observed dip of $15^{\circ}$ for the detachment, the exhumation of the footwall becomes half Brichau et al.'s [2008] estimates, close to $8 \mathrm{~km}$. Note that these estimates are derived from low-temperature thermochronology and therefore that they constrain only the last brittle part of the detachment history, i.e., that which was accommodated by the Mykonos detachment. Given the observation made by Brichau et al. [2008] that the oldest FT ages are close to the ${ }^{40} \mathrm{Ar}^{39} \mathrm{Ar}$ ages, the ductile part of the exhumation must have been fast and short in time. If we assume a constant exhumation rate throughout, ductile exhumation during 
granite cooling cannot have been large. The Livada detachment juxtaposes rocks types that were already in contact at the time of intrusion confirming that the amount of displacement was not very large. But it does not mean that it was negligible: as the detachment somehow reactivates the intrusive contact and as the granite crops out on more than $9 \mathrm{~km}$ parallel to the direction of motion, several kilometers of displacement are possible. The Mykonos detachment has thus accommodated a large part of the footwall exhumation. Although errors bars are very large on the estimation of the finite displacement (see above) it is likely that several tens of kilometers of horizontal extension have been taken by the two detachments with a low average dip.

\subsection{Overall Geometry and Kinematics of Extensional Deformation on Mykonos and Regional Significance}

[34] The observations described above show the progressive formation of a brittle detachment (Mykonos detachment) that controls the deposition of syn-tectonic sediments in its hanging wall. This detachment is entirely brittle and is roughly parallel to a deeper ductile detachment (Livada detachment) that is localized along the intrusive contact between the Upper Cycladic Unit and the granite. Intrusion, cooling and mylonitization of the granite were contemporaneous with the top-to-the-NE shear along a shallow-dipping ductile shear zone that evolved with time toward brittle behavior. Both the Livada and the Mykonos detachments were likely low-dipping throughout their history of activity.

[35] Some $13 \mathrm{Ma}$ ago, in the overall post-orogenic extensional context of the Aegean Sea, a granite intruded the Upper Cycladic Unit in the brittle crust, granitic sills and dikes impinging the base of the metabasites (Figure 13a). The brittle-ductile transition migrated upward during the intrusion and shear was then localized at the contact of the granite with the metabasites; this contact was therefore ductilely sheared and folded (Livada detachment). Then, extension was brittlely accommodated in metabasites by low-angle or steep faults partly reactivating the ductile shear zone. A brittle detachment, associated to a cataclastic damage zone (Mykonos detachment) formed higher up while the granite produced enriched barite and Fe-hydroxide fluids forming sub-vertical veins and dikes into the upper units. The Mykonos detachment formed during the deposition of late Miocene sediments, thus after the granite cooling, and consequently after the Livada detachment. The deformation was progressively localized and transferred upward from the ductile Livada detachment to the brittle Mykonos detachment. The deformation was then principally accommodated by the cataclastic detachment under a N20 extensional trend. In the hanging wall of the brittle detachment, the deformation was accommodated by steep faults rooting into the detachment (Figure 13b). While the two detachments were probably, at least partly, active at the same time, lineation in the granite and early formed brittle extensional features were both progressively rotated clockwise about a vertical axis. During cooling, the rigid part of the granite also recorded a rotation about an horizontal axis due to shearing and the brittle-ductile transition migrated downward favoring the reactivation of the ductile detachment in brittle conditions during the last increment of deformation. New faults and veins oriented $\mathrm{N} 110^{\circ}$ in the sedimentary rocks, and faults in the metabasites in Cape Evros, consistent with $\mathrm{N} 20^{\circ}$ extension, were superimposed onto early formed passively rotated structures. The structures of the hanging wall sedimentary rocks were finally tilted (Panormos Bay) during formation of a local roll-over structure due to the flat and ramp geometry of the detachment (Figure 13c).

[36] The Livada and Mykonos detachments are part of a series of north-dipping detachments running from Andros to Mykonos, and further east until Ikaria at least, making together the North Cycladic Detachment System [Jolivet et al., 2010]. A large displacement is recognized along these shallow-dipping structures even in the brittle regime. Before the intrusion of the Tinos and Mykonos granites, the same structural system had already accommodated several tens of kilometers of slip, already with a low dip. In Tinos it is debatable whether or not the end of exhumation, in the brittle field, was accommodated by a shallow-dipping structure, as no sedimentary rocks are present there in the upper plate. This question is partly answered in Mykonos where the so-called Mykonos detachment was active with a low dip at shallow crustal levels. It is thus likely that most of the exhumation from the ductile to the brittle domain, and quite high up in the upper crust was achieved below a lowdipping detachment system. The role played by later steep faults thus appears quite minor. It is possible that those steep faults were more important toward the west when considering their geometry east of Mount Olympos and in the Ossa-Pelion region [Lacassin et al., 2007]. Low-angle detachments would thus play a more important role in exhumation toward the center of the Cyclades where the crust is warmer. Characterizing the overall crustal rheology is beyond the scope of this paper, but further studies should be conducted to address the question of the respective contributions of shallowdipping and steep faults in the final exhumation of metamorphic core complexes. The role played by granitic intrusions in lifting the brittle-ductile transition temporarily up during extension should be explored as well.

\section{Conclusions}

[37] Field observations provide constraints on the overall geometry and kinematics of deformation related to postorogenic extension in Mykonos. The extensional deformation is localized along a two-branch detachment system whose lower branch, active in the ductile regime, can be correlated to the Livada detachment cropping out in the eastern part of Tinos, and whose upper branch, the Mykonos detachment, is active in the brittle field and controls the deposition of syn-extension sediments in the late Miocene. Soft-sediment deformation and the vein and fault network attest for slip along the Mykonos brittle detachment at shallow depth with a very shallow dip, close to the present geometry. The deformation is localized in space and time along the two branches of the detachment, which could have been active contemporary in relay, in response to the migration of the brittle-ductile transition. The Mykonos brittle detachment was active at the same time and after the Livada ductile detachment and the associated thick ductile shear 
A - Granitic intrusion (14-9 Ma) into the Upper Cycladic Unit and onset of the localization of the deformation on the Livada ductile detachment

SW

NE
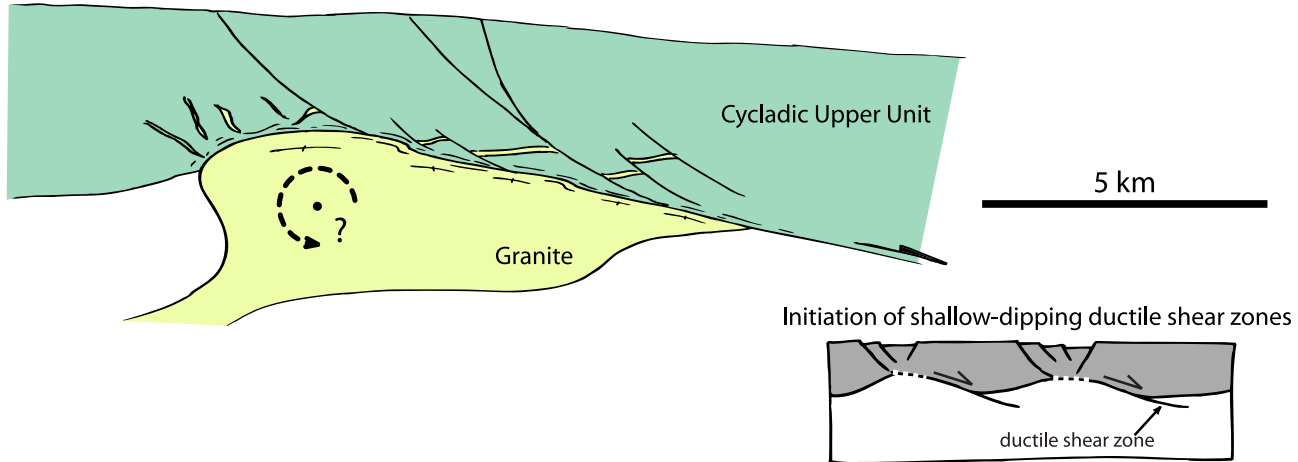

B - Onset of the localization of the deformation on the Mykonos brittle cataclastic detachment

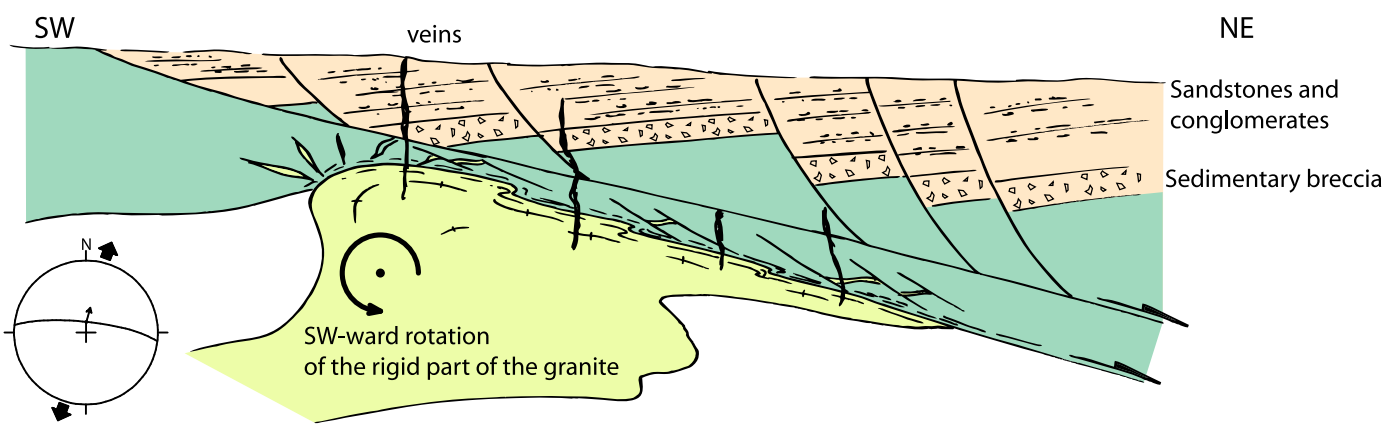

C - Mainly localized deformation on the Mykonos brittle cataclastic detachment and clockwise rotation of the whole structure about a vertical axis

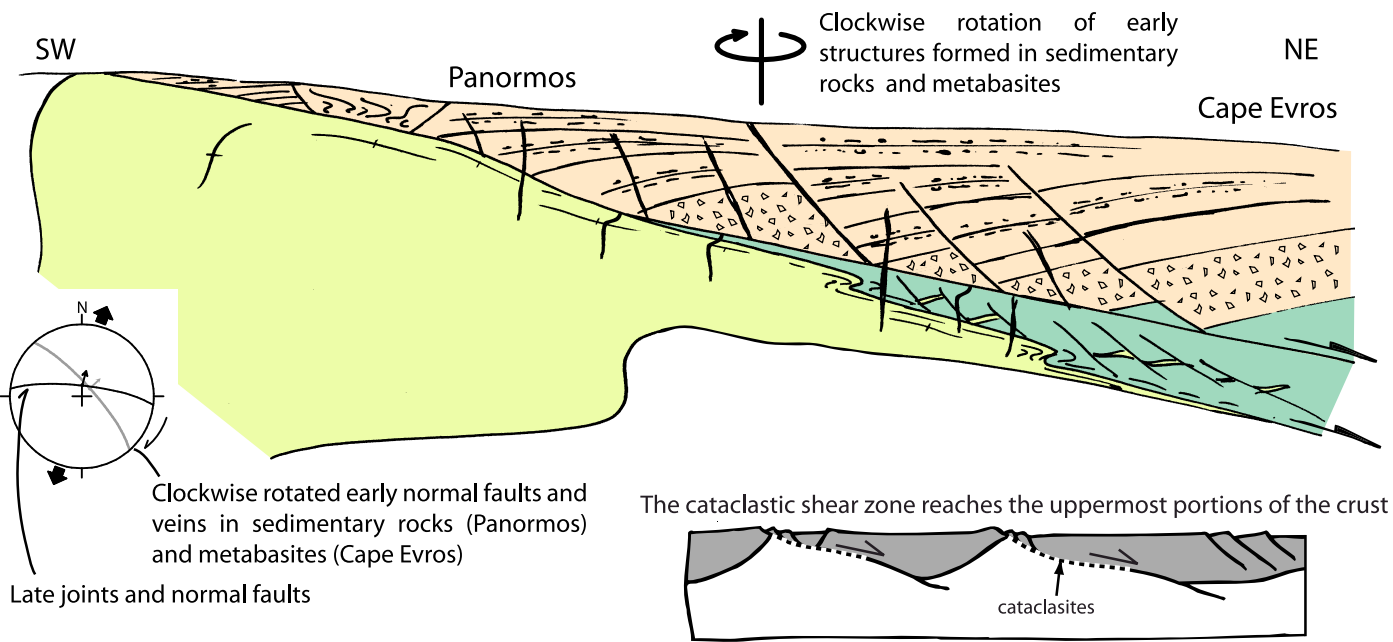

Figure 13. Scenario of crustal-scale evolution of the detachment system on Mykonos. See text for explanations.

zone that affects the Mykonos granite. These two detachments represent the last stages of the North Cycladic Detachment System, a shallow-dipping extensional structure observed along the whole northern Cyclades islands. We interpret paleomagnetic data in the footwall as rotation of the rigid part of the granite below the Mykonos and Livada detachments as an alternative to the more classical interpretation of a rotation and tilting of the detachment itself as would occur in a rolling-hinge mechanism for instance. 
[38] The contribution of this paper to the long-lived debate on the initial attitude and kinematics of detachments and formation of Metamorphic Core Complexes is thus to emphasize that brittle slip on the (Mykonos) detachment unambiguously occurred while it was at very low dip, and that paleomagnetically constrained rotation about an horizontal axis of the footwall granite does not require a steeper dip for the detachment. The evidence come from the hanging wall rift basin deposits that are in many places shallowly dipping, and have locally steep dip domains in opposite directions. Upper crustal blocks can therefore rotate beneath a flat detachment, as is often observed at outcrop scale in shear zones. In addition, because the cataclastic- brittle slip along the detachment occurred at shallow dip, the sub-vertical attitude of the maximum principal stress as derived from minor joints, veins and normal faults as well from subvertical barite dikes argue in favor of the mechanical weakness of the Mykonos detachment, as recently discussed by Collettini et al. [2009] for the Zuccale fault in Elba.

[39] Acknowledgments. This is a contribution to the ANR EGEO Project. Thanks are due to $\mathrm{B}$. Wernicke and two anonymous reviewer who provided really useful suggestions to improve and clarify the manuscript.

\section{References}

Altherr, R., and W. Siebel (2002), I-type plutonism in a continental back-arc setting: Miocene granitoids and monzonites from the central Aegean Sea, Greece, Contrib. Mineral. Petrol., 143, 397-415.

Altherr, R., M. Schliestedt, M. Okrusch, E. Seidel, H. Kreuzer, W. Harre, H. Lenz, I. Wendt, and G. A. Wagner (1979), Geochronology of highpressure rocks on Sifnos (Cyclades, Greece), Contrib. Mineral. Petrol., 70, 245-255, doi:10.1007/ BF00375354.

Altherr, R., H. Kreuzer, I. Wendt, H. Lenz, G. H Wagner, J. Keller, W. Harre, and A. Hohndorf (1982), A late Oligocene/early Miocene high temperature belt in the Attic-Cycladic crystalline complex (SE Pelagonian, Greece), Geol. Jahrb., Reihe E, E23, 97-164.

Avigad, D., and Z. Garfunkel (1989), Low-angle faults above and below a blueschist belt: Tinos Island, Cyclades, Greece, Terra Nova, 1, 182-187, doi:10.1111/j.1365-3121.1989 tb00350.x.

Avigad, D., and Z. Garfunkel (1991), Uplift and exhumation of high-pressure metamorphic terranes: The example of the Cycladic blueschists belt (Aegean Sea), Tectonophysics, 188, 357-372, doi:10.1016/ 0040-1951(91)90464-4

Avigad, D., Z. Garfunkel, L. Jolivet, and J. M. Azañón (1997), Back-arc extension and denudation of Mediterranean eclogites, Tectonics, 16, 924-941, doi:10.1029/97TC02003.

Avigad, D., G. Baer, and A. Heimann (1998), Block rotations and continental extension in the central Aegean Sea: Palaeomagnetic and structural evidence from Tinos and Mykonos (Cyclades, Greece), Earth Planet. Sci. Lett., 157, 23-40, doi:10.1016/ S0012-821X(98)00024-7.

Avigad, D., A. Ziv, and Z. Garfunkel (2001), Ductile and brittle shortening, extension-parallel folds and maintenance of crustal thickness in the central Aegean (Cyclades, Greece), Tectonics, 20, 277-287, doi:10.1029/2000TC001190.

Barchi, R. M., G. Minelli, and G. Pialli (1998), The CROP 03 profile: A synthesis of results on deep structures of the northern Apennines, Mem. Soc. Geol. Ital., 52, 383-400.

Bonneau, M. (1982), Evolution géodynamique de l'arc égéen depuis le Jurassique Supérieur jusqu'au Miocène, Bull. Soc. Geol. Fr., 7, 229-242.

Bonneau, M., and J. R. Kienast (1982), Subduction, collision et schistes bleu: Exemple de l'Egée, Grèce, Bull. Soc. Geol. Fr., 7, 785-791.

Brichau, S., U. Ring, R. A. Ketcham, A. Carter, D. Stockli, and M. Brunel (2006), Constraining the long-term evolution of the slip rate for a major extensional fault system in the central Aegean, Greece, using thermochronology, Earth Planet. Sci. Lett., 241,293-306, doi:10.1016/j.eps1.2005.09.065.
Brichau, S., U. Ring, A. Carter, P. Monié, R. Bolhar, D. Stockli, and M. Brunel (2007), Extensional faulting on Tinos Island, Aegean Sea, Greece: How many detachments?, Tectonics, 26, TC4009, doi:10.1029/ 2006TC001969.

Brichau, S., U. Ring, A. Carter, R. Bolhar, P. Monié, D. Stockli, and M. Brunel (2008), Timing, slip rate, displacement and cooling history of the Mykonos detachment footwall, Cyclades, Greece, and implications for the opening of the Aegean Sea basin, J. Geol. Soc., 165, 263-277, doi:10.1144/001676492006-145.

Brun, J. P., D. Sokoutis, and J. Van Den Driessche (1994), Analogue modeling of detachment fault systems and core complexes, Geology, 22, 319-322, doi:10.1130/0091-7613(1994)022<0319: AMODFS $>2.3 . \mathrm{CO} ; 2$

Buck, W. R. (1988), Flexural rotation of normal faults, Tectonics, 7, 959-973, doi:10.1029/ TC007i005p00959.

Chéry, J. (2001), Core complex mechanics: From the Gulf of Corinth to the Snake Range, Geology, 29 (5), 439-442, doi:10.1130/0091-7613(2001) $029<0439$ :CCMFTG $>2.0 . \mathrm{CO} ; 2$

Collettini, C., A. Niemeijer, C. Viti, and C. Marone (2009), Fault zone fabric and fault weakness, Nature, 462, doi:10.1038/nature 08585 .

Crittenden, M. D., Jr., P. J. Coney, and G. H. Davis (Eds.) (1980), Cordilleran Metamorphic Core Complexes, Mem. Geol. Soc. Am., 153, 490 pp.

Davis, G. H. (1983), Shear-zone model for the origin of metamorphic core complexes, Geology, 11, 342347, doi:10.1130/0091-7613(1983)11<342: $\mathrm{SMFTOO}>2.0 . \mathrm{CO} ; 2$

Davis, G. H., and P. J. Coney (1979), Geologic development of the Cordilleran metamorphic core complexes, Geology, 7, 120-124, doi:10.1130/00917613(1979)7<120:GDOTCM $>2.0 . C O ; 2$.

Davis, G. A., and G. S. Lister (1988), Detachment faulting in continental extension; Perspectives from the southwestern U.S. Cordillera, in Processes in Continental Lithospheric Deformation, edited by S. P. J. Clark, Spec. Pap. Geol. Soc. Am., 218, 133-159.

Dürr, S., and R. Altherr (1979), Existence des klippes d'une nappe composite neogene dans l'île de Myconos/Cyclades (Grece), Rapp. Comm. Int. Mer Medit., 25/26(2a), 33-34.

Dürr, S., E. Seidel, H. Kreuzer, and W. Harre (1978), Témoins d'un métamorphisme d'âge crétacé supérieur dans 1'Egéide: Datations radiométriques de minéraux provenant de l'île de Nikouria (Cyclades, Grèce), Bull. Soc. Geol. Fr., 20, 209-213.

Famin, V., P. Philippot, L. Jolivet, and P. Agard (2004), Evolution of hydrothermal regime along a crustal shear zone, Tinos Island, Greece, Tectonics, 23, TC5004, doi:10.1029/2003TC001509.
Famin, V., R. Hébert, P. Philippot, and L. Jolivet (2005), Ion probe and fluid inclusion evidence for co-seismic fluid infiltration in a crustal detachment, Contrib. Mineral. Petrol., 150, 354-367, doi:10.1007/ s00410-005-0031-x

Faure, M., M. Bonneau, and J. Pons (1991), Ductile deformation and syntectonic granite emplacement during the late Miocene extension of the Aegean (Greece), Bull. Soc. Geol. Fr, 162, 3-12.

Froitzheim, N., and G. P. Eberli (1990), Extensional detachment faulting in the evolution of a Tethys passive continental margin, Eastern Alps, Switzerland, Geol. Soc. Am. Bull., 102, 1297-1308, doi:10.1130/00167606(1990)102<1297:EDFITE $>2.3 . C O ; 2$.

Gautier, P., and J. P. Brun (1994a), Crustal-scale geometry and kinematics of late-orogenic extension in the central Aegean (Cyclades and Evvia island) Tectonophysics, 238, 399-424, doi:10.1016/0040 1951(94)90066-3.

Gautier, P., and J. P. Brun (1994b), Ductile crust exhumation and extensional detachments in the centra Aegean (Cyclades and Evvia islands), Geodin. Acta, $7,57-85$

Gautier, P., J. P. Brun, and L. Jolivet (1993), Structure and kinematics of upper Cenozoic extensional detachment on Naxos and Paros (Cyclades Islands, Greece), Tectonics, 12, 1180-1194, doi:10.1029/ 93TC01131

Gautier, P., J. P. Brun, R. Moriceau, D. Sokoutis J. Martinod, and L. Jolivet (1999), Timing, kinematics and cause of Aegean extension: A scenario based on a comparison with simple analogue experiments, Tectonophysics, 315(1-4), 31-72, doi:10.1016/S0040-1951(99)00281-4.

Gueydan, F., Y. Leroy, L. Jolivet, and P. Agard (2003), Analysis of continental midcrustal strain localization induced by microfracturing and reaction-softening J. Geophys. Res., 108(B2), 2064, doi:10.1029/ 2001JB000611.

Gueydan, F., Y. Leroy, and L. Jolivet (2004), Mechanics of low-angle extensional shear zones at the brittle-ductile transition, J. Geophys. Res., 109 B12407, doi:10.1029/2003JB002806.

Johnson, R. A., and K. L. Loy (1992), Seismic reflection evidence for seimogenic low-angle faulting in southeastern Arizona, Geology, 20, 597-600, doi: $10.1130 / 0091-7613(1992) 020<0597$ : SREFSL $>2.3 . C O ; 2$

Jolivet, L., and J. P. Brun (2008), Cenozoic geodynamic evolution of the Aegean region, Int. J. Earth Sci. 99, 109-138, doi:10.1007/s00531-008-0366-4.

Jolivet, L., and C. Faccenna (2000), Mediterranean extension and the Africa-Eurasia collision, Tectonics, 19(6), 1095-1106, doi:10.1029/2000TC900018.

Jolivet, L., J. M. Daniel, C. Truffert, and B. Goffe (1994), Exhumation of deep crustal metamorphic rocks and crustal extension in arc and back-arc 
regions, Lithos, 33, 3-30, doi:10.1016/0024-4937 (94)90051-5

Jolivet, L., and M. Patriat (1999), Ductile extension and the formation of the Aegean Sea, in The Mediterranean Basins: Tertiary Extensions Within the Alpine Orogen, edited by B. Durand et al., Geol. Soc. Spec. Publ., 156, 427-456, doi:10.1144/GSL. SP.1999.156.01.20

Jolivet, L., E. Lecomte, B. Huet, Y. Denèle, O. Lacombe, L. Labrousse, L. Le Pourhiet, and C. Mehl (2010), The North Cycladic Detachment System, Earth Planet. Sci. Lett., 289, 87-104, doi:10.1016/j. eps1.2009.10.032.

Kumerics, C., U. Ring, S. Brichau, J. Glodny, and P. Monié (2005), The extensional Messaria shear zone and associated brittle detachment faults, Aegean Sea Greece, J. Geol. Soc., 162, 701-721, doi:10.1144/0016-764904-041.

Lacassin, R., N. Arnaud, P. H. Leloup, R. Armijo, and B. Meyer (2007), Exhumation of metamorphic rocks in N Aegean: The path from shortening to extension and extrusion, eEarth Discuss., 2, 1-35, doi:10.5194/eed-2-1-2007.

Lee, J., and G. S. Lister (1992), Late Miocene ductile extension and detachment faulting, Mykonos, Greece, Geology, 20, 121-124, doi:10.1130/00917613(1992)020<0121:LMDEAD >2.3.CO;2.

Le Pichon, X. (1982), Land-locked oceanic basins and continental collision: The Eastern Mediterranean as a case example, in Mountain Building Processes, edited by K. J. Hsue, pp. 201-211, Academic, London.

Le Pichon, X., and J. Angelier (1979), The Hellenic arc and trench system: A key to the neotectonic evolution of the eastern Mediterranean area, Tectonophysics, 60, 1-42, doi:10.1016/0040-1951(79)90131-8.

Le Pourhiet, L., E. Burov, and I. Moretti (2004), Rifting through a stack of inhomogeneous thrusts (the dipping pie concept), Tectonics, 23, TC4005, doi:10.1029/2003TC001584.

Le Pourhiet, L., L. Mattioni, and I. Moretti (2006), 3D modelling of rifting through a pre-existing stack of nappes in the Gulf of Corinth (Greece) a mixed analogue/numerical approach, in Analogue and Numerical Modelling of Crustal-Scale Processes, edited by S. Buiter and G. Schreurs, Geol. Soc. Spec. Publ., 253, 233-252, doi:10.1144/GSL.SP. 2006.253.01.12.

Lister, G. S., and G. A. Davis (1989), The origin of metamorphic core complexes and detachment faults formed during Tertiary continental extension in the northern Colorado River region, U.S.A, J. Struct. Geol., 11, 65-94, doi:10.1016/0191-8141(89) 90036-9.

Lister, G. S., G. Banga, and A. Feenstra (1984), Metamorphic core complexes of cordilleran type in the Cyclades, Aegean Sea, Greece, Geology, 12, 221-225, doi:10.1130/0091-7613(1984)12<221: $\mathrm{MCCOCT}>2.0 . \mathrm{CO} ; 2$
Longwell, C. R. (1945), Low-angle normal faults in the Basin and Range Province, Eos AGU Trans., 26, $107-118$

Lucas, I. (1999), Le pluton de Mykonos-Delos-Rhenee (Cyclades, Grèce): Un exemple de mise en place synchrone de l'extension crustale, Thèse de doctorat, 491 pp., Univ. d'Orléans, Orléans, France.

Mehl, C., L. Jolivet, and O. Lacombe (2005), From ductile to brittle: Evolution and localization of deformation below a crustal detachment (Tinos, Cyclades, Greece), Tectonics, 24, TC4017, doi:10.1029/ 2004TC001767.

Mehl, C., L. Jolivet, O. Lacombe, L. Labrousse, and G. Rimmele (2007), Structural evolution of Andros Island (Cyclades, Greece): A key to the behaviour of a (flat) detachment within an extending continental crust, in The Geodynamics of the Aegean and Anatolia, edited by T. Taymaz et al., Geol. Soc. Spec. Publ., 291, 41-73, doi:10.1144/SP291.3.

Melosh, H. J. (1990), Mechanical basis for low-angle normal faulting in the Basin and Range province, Nature, 343, 331-335, doi:10.1038/343331a0.

Morris, A., and M. Anderson (1996), First paleomagnetic results from the Cycladic Massif, Greece, and their implication for Miocene extension directions and tectonic models in the Aegean, Earth Planet. Sci. Lett., 142, 397-408, doi:10.1016 0012-821X(96)00114-8

Papanikolaou, D. (1987), Tectonic evolution of the Cycladic blueschist belt (Aegean Sea, Greece), in Chemical Transport in Metasomatic Processes, edited by H. C. Helgeson, pp. 429-450, D. Reidel, Dordrecht, Netherlands.

Regenauer-Lieb, K., R. F. Weinberg, and G. Rosenbaum (2006), The effect of energy feedbacks on continental strength, Nature, 442, 67-70, doi:10.1038/ nature 04868 .

Reynolds, S. J., and J. E. Spencer (1985), Evidence for large-scale transport on the Bullard detachment fault, west-central Arizona, Geology, 13, 353-356, doi:10.1130/0091-7613(1985)13<353:EFLTOT> 2.0.CO;2.

Rigo, A., H. Lyon-Caen, R. Armijo, A. Deschamps, D. Hatzfeld, K. Makropoulos, P. Papadimitriou, and I. Kassaras (1996), A microseismicity study in the western part of the Gulf of Corinth (Greece) Implications for large-scale normal faulting mechanisms, Geophys. J. Int., 126, 663-688.

Ring, U., S. Laws, and M. Bernet (1999), Structural analysis of a complex nappe sequence and late-orogenic basins from the Aegean Island of Samos, Greece, J. Struct. Geol., 21, 1575-1601, doi:10.1016/ S0191-8141(99)00108-X.

Ring, U., S. N. Thomson, and M. Bröcker (2003), Fast extension but little exhumation: The Vari detachment in the Cyclades, Greece, Geol. Mag., 140(3), 245-252, doi:10.1017/S0016756803007799.

Sanchez-Gomez, M., D. Avigad, and A. Heiman (2002), Geochronology of clasts in allochthonous
Miocene sedimentary sequences on Mykonos and Paros islands: Implications for back-arc extension in the Aegean Sea, J. Geol. Soc., 159, 45-60, doi:10.1144/0016-764901031.

Scott, R. J., and G. Lister (1992), Detachment faults: Evidence for a low-angle origin, Geology, 20 , 833-836, doi:10.1130/0091-7613(1992)020<0833: DFEFAL $>2.3 . \mathrm{CO} ; 2$

Skarpelis, N. (2002), Geodynamics and evolution of the Miocene mineralisations in the Cycladic-Pelagonian belts, Hellenides, Bull. Geol. Soc. Greece, 34(6), 2191-2206.

Sorel, D. (2000), A Pleistocene and still-active detachment fault and the origin of the Corinth-Patras rift, Greece, Geology, 28, 83-86, doi:10.1130/00917613(2000)28<83:APASDF $>2.0 . \mathrm{CO} ; 2$.

Spencer, J. E., and C. G. Chase (1989), Role of crustal flexure in initiation of low-angle normal faults and implications for structural evolution of the Basin and Range province, J. Geophys. Res., 94, 17651775, doi:10.1029/JB094iB02p01765.

Van Hinsbergen, D. J. J., C. G. Langereis, and J. E. Meulenkamp (2005), Revision of timing, magnitude and distribution of Neogene rotations in the western Aegean region, Tectonophysics, 396, 1-34, doi:10.1016/j.tecto.2004.10.001.

Voreadis, G. D. (1961), Die Geologie und die Barytlagerstätten der Inseln Mykonos and Dragonissi, Ann. Geol. Pays Helléniques, 12, 263-300.

Walcott, C. R. and S. H. White (1998), Constraints on the kinematics of post-orogenic extension imposed by stretching lineations in the Aegean region, Tectonophysics, 298, 155-175, doi:10.1016/S0040-1951 (98)00182-6.

Wernicke, B. (1981), Low-angle normal faults in the Basin and Range province: Nappe tectonics in an extending orogen, Nature, 291, 645-648, doi:10.1038/291645a0.

Wernicke, B. P., and G. J. Axen (1988), On the role of isostasy in the evolution of normal fault systems, Geology, 16, 848-851, doi:10.1130/0091-7613 (1988)016<0848:OTROII >2.3.CO;2.

Wernicke, B., J. D. Walker, and M. S. Beaufait (1985), Structural discordance between Neogene detachments and frontal Sevier thrusts, central Mormon Mountains, southern Nevada, Tectonics, 4, 213 246, doi:10.1029/TC004i002p00213.

Yin, A. (1989), Origin of regional, rooted low-angle normal faults: A mechanical model and its tectonic implications, Tectonics, 8, 469-482, doi:10.1029/ TC008i003p00469.

Y. Denèle, L. Jolivet, L. Labrousse, O. Lacombe, E. Lecomte, and L. Le Pourhiet, ISTeP, UMR 7193 UPMC Université Paris 6, CNRS, T46-55, E1, Boite 129, 4 pl. Jussieu, F-75005, Paris CEDEX 5, France. (olivier.lacombe@upmc.fr) 